\title{
A musculoskeletal model of low grade connective tissue inflammation in patients with thyroid associated ophthalmopathy (TAO): the WOMED concept of lateral tension and its general implications in disease
}

\author{
Roy Moncayo* and Helga Moncayo
}

Address: WOMED, Karl-Kapferer-Strasse 5, A-6020 Innsbruck, Austria

Email: Roy Moncayo* - anmeldung@womed.at; Helga Moncayo - anmeldung@womed.at

* Corresponding author

Published: 23 February 2007

BMC Musculoskeletal Disorders 2007, 8:17 doi:10.1/86/147|-2474-8-17

This article is available from: http://www.biomedcentral.com/I47/-2474/8/17

(c) 2007 Moncayo and Moncayo; licensee BioMed Central Ltd.

This is an Open Access article distributed under the terms of the Creative Commons Attribution License (http://creativecommons.org/licenses/by/2.0), which permits unrestricted use, distribution, and reproduction in any medium, provided the original work is properly cited.
Received: 4 September 2006 Accepted: 23 February 2007

\begin{abstract}
Background: Low level connective tissue inflammation has been proposed to play a role in thyroid associated ophthalmopathy (TAO). The aim of this study was to investigate this postulate by a musculoskeletal approach together with biochemical parameters.

Methods: 13 patients with TAO and 16 controls were examined. Erythrocyte levels of $\mathrm{Zn}, \mathrm{Cu}$, $\mathrm{Ca}^{2+}, \mathrm{Mg}$, and $\mathrm{Fe}$ were determined. The musculoskeletal evaluation included observational data on body posture with emphasis on the orbit-head region. The angular foot position in the frontal plane was quantified following gait observation. The axial orientation of the legs and feet was evaluated in an unloaded supine position. Functional propioceptive tests based on stretch stimuli were done by using foot inversion and foot rotation.

Results: Alterations in the control group included neck tilt in 3 cases, asymmetrical foot angle during gait in 2, and a reaction to foot inversion in 5 cases. TAO patients presented facial asymmetry with displaced eye fissure inclination (mean $9.1^{\circ}$ ) as well as tilted head-on-neck position (mean $5.7^{\circ}$ ). A further asymmetry feature was external rotation of the legs and feet (mean $27^{\circ}$ ). Both foot inversion as well as foot rotation induced a condition of neuromuscular deficit. This condition could be regulated by gentle acupressure either on the lateral abdomen or the lateral ankle at the acupuncture points gall bladder 26 or bladder 62 , respectively. In 5 patients, foot rotation produced a phenomenon of moving toes in the contra lateral foot. In addition foot rotation was accompanied by an audible tendon snapping. Lower erythrocyte $\mathrm{Zn}$ levels and altered correlations between $\mathrm{Ca}^{2+}, \mathrm{Mg}$, and $\mathrm{Fe}$ were found in TAO.
\end{abstract}

Conclusion: This whole body observational study has revealed axial deviations and body asymmetry as well as the phenomenon of moving toes in TAO. The most common finding was an arch-like displacement of the body, i.e. eccentric position, with foot inversion and head tilt to the contra lateral side and tendon snapping. We propose that eccentric muscle action over time can be the basis for a low grade inflammatory condition. The general implications of this model and its relations to $\mathrm{Zn}$ and Se will be discussed. 


\section{Background}

The pathogenesis of orbital changes seen in patients with thyroid associated orbitopathy (TAO) has been matter of research since decades $[1,2]$. One theory that has eluded confirmation is the proposal of a low level inflammation of the connective tissue [3-5]. The original idea put forth in 1995 by the research group of Jack R. Wall [3] has found limited resonance in the scientific literature (citation analysis done with SCOPUS, Elsevier B.V.). On the other hand, the topic of low grade inflammation is found more frequently in relation to the metabolic syndrome, to abdominal obesity and to cardiovascular disease as well as in relation to decreased muscle mass and elevated cytokine levels, e.g. of IL-6 and TNF [6-9]. A common denominator found both in TAO as well as in these metabolic situations is the elevation of cytokines [10-13]. It is interesting to emphasize, that effective treatment of the thyroid condition related to TAO, i.e. hyperthyroidism, does not lead to a normalization of IL- 6 levels in these patients [11] which suggests that IL- 6 might not originate from the thyroid [14]. On the other hand, physiology research has demonstrated that muscle tissue can indeed produce IL-6 and TNF [15]. In spite of this fact, the role of peripheral skeletal muscle function has been seldom evaluated in TAO. None the less muscular changes have been quantified in thyroid diseases showing a situation of diminished strength [16-18]. Therapeutical consequences, however, have not been derived from these dynamometric findings.

Elevation of glycosaminoglycans (GAGs) has also been described to occur in TAO $[19,20]$, however the mechanisms linking GAGs to inflammation are intricate [21] and elevated GAGs can be found in patients with other autoimmune diseases [22]. In cases of recurrent of eye disease levels of GAGs can again be elevated [23]. A recent publication on TAO concluded that "the elevations in urinary GAGs in these patients appear to reflect widespread stimulation of fibroblast metabolic processes, as might occur in the setting of systemic connective tissue inflammation" [24]. Mechanisms leading to GAGs elevation in relation to connective tissue can be the scarring of fasciae [25] as well as endoplasmatic reticulum (ER) stress [26]. GAGs are also related to the extra cellular superoxide dismutase system (EC-SOD) [27]. SOD has been found to be elevated in GD, and remains so even after an euthyroid state has been achieved [28].

Due to the involvement of extra ocular muscles (EOM) in TAO, investigators have also studied the role of these tissues as a potential antigenic target. Based on serological methods, putative muscle antigens have been identified in EOM as well as in peripheral muscle tissue $[29,30]$. On clinical grounds, Graves' disease can present features such as myalgia, swelling of the calves and fasciitis [31]. Symp- tomatology of amyotrophic lateral sclerosis has also been reported in association with thyroid disease [32-34]. The evaluation of muscle strength in hyperthyroid patients has revealed a situation of reduced strength which can be regained after therapy [16,18]. In 1977 Delporte et al. found an association with musculoskeletal components such as with polymyositis [35,36]. In another study an eosinophilic fasciitis was found [37]. In 1977 one report described manifestations of muscular and neurological origin in hyperthyroidism. The authors called the situation hyperthyroid myopathy, a condition which was not necessarily proportional to the hyperthyroid state, and proposed also a polysystemic nature of Grave's disease [38]. Finally, motor neuron alterations have also been described in connection with hyperthyroidism [34,39].

Two recent findings clearly emphasize the relation of TAO to musculoskeletal structures. In the first place antibodies directed against a muscle antigen which is involved in $\mathrm{Ca}^{2+}$ release, i.e. myocardial calsequestrin, have also been described [40]. $\mathrm{Ca}^{2+}$ release is an immediate regulator of muscle contraction [41-43]. In the second place, antibodies directed against collagen type XIII have also been found [44]. Collagen type XIII is found at the myotendinous junctions [45].

Besides these clinical and serological aspects, imaging methods have also provided hints regarding the involvement of musculoskeletal structures. Recently it has been shown that muscles of patients with Graves' disease present increased peripheral glucose utilization, i.e. ${ }^{18} \mathrm{~F}-$ fluorodeoxyglucose uptake [46]. Increased peripheral glucose metabolism can either signalize inflammatory changes [47] or increased tissue metabolism such as in oncological conditions [48]. Indirect evidence on the presence of inflammation in muscles of TAO patients, e.g. neck muscles and shank, can be seen through the use of radioactive labeled octreotide, a somatostatin analog $[49,50]$. Furthermore it should be kept in mind that posture - a neuronal and musculoskeletal function - is intimately related to gaze $[51,52]$, and gaze is altered in TAO. Again, these lines of evidence suggest an interaction with the musculoskeletal system in TAO. One possible explanation for the scarcity of clinical evaluations in this direction is the lack of sufficient clinical expertise in the field of musculoskeletal diseases $[53,54]$.

Considering the compelling amount of evidence mentioned above it appears that both the musculoskeletal system and the connective tissue system can be involved in TAO. The aims of the study were to analyze and characterize musculoskeletal elements in TAO patients using a simple functional manual clinical examination method. The elements in this analysis were derived from features of biomechanical functions that relate the feet to eye func- 
tion $[51,52,55]$. The presence of potential somatic dysfunction was studied using a propioceptive stretch test [56]. Finally erythrocyte levels of $\mathrm{Zn}$ and $\mathrm{Cu}$, which are closely related to the function of superoxide dismutase (SOD) [57-59], as well as the levels of $\mathrm{Mg}$ and $\mathrm{Ca}^{2+}$, which are important in muscle action, were also analyzed.

\section{Patients and Methods}

The clinical and laboratory study included 13 patients with TAO, 12 females and 1 male, age range 10-46 years and 16 controls, 11 females and 5 males, age range 15 to 58 years. According to the Werner classification [60], all patients were in stages I or II. Mild signs of inflammatory activity in the form of conjunctivitis were present in 3 cases. All patients provided written consent for participation and for their identities to be revealed. At the time of the investigation, latent hyperthyroidism was present in 5 patients. Informed consent was provided. The investigation was carried out in accordance with the Declaration of Helsinki. The institutional ethics committee approved the study. The investigation was done by endocrinologists trained also in musculoskeletal methods (Applied Kinesiology) as well as in acupuncture. Additional expertise on sports physiology and physical training was contributed by RM (Master of Advanced Studies Health and Fitness, University of Salzburg, Austria). Neither specialized biomechanical methods nor a biomechanical research facility were available.

The initial clinical examination started with the patient sitting and then standing in front of the investigator. For the observations on posture the $3 \mathrm{D}$ coordinates were defined as follows: the positive $\mathrm{x}$ direction was the forward orientation, the positive y direction was the rightward orientation, and the positive $\mathrm{z}$ direction was the upward orientation (Figure 1). Some facial characteristics such as the inter-pupillary angle and the head on neck orientation [61] were quantitatively evaluated using digital photographic material.

Symmetry of foot movement during gait was observed in the frontal plane. For this the patient was asked to walk an aisle of 10 meters length. After observing the gait pattern the patient was asked to repeat the procedure and to stop on command during the stance phase of the representative side. While standing the angular deviation of the foot in relation to the straight direction of motion was measured. This procedure was adapted from the method described by Schmid [62].

The last part of the examination was conducted with the patient in an unloaded supine position where the orientation of the legs and of the feet was evaluated. This unloaded supine position has been described as being adequate for the mobilization of the stretch reflex path-

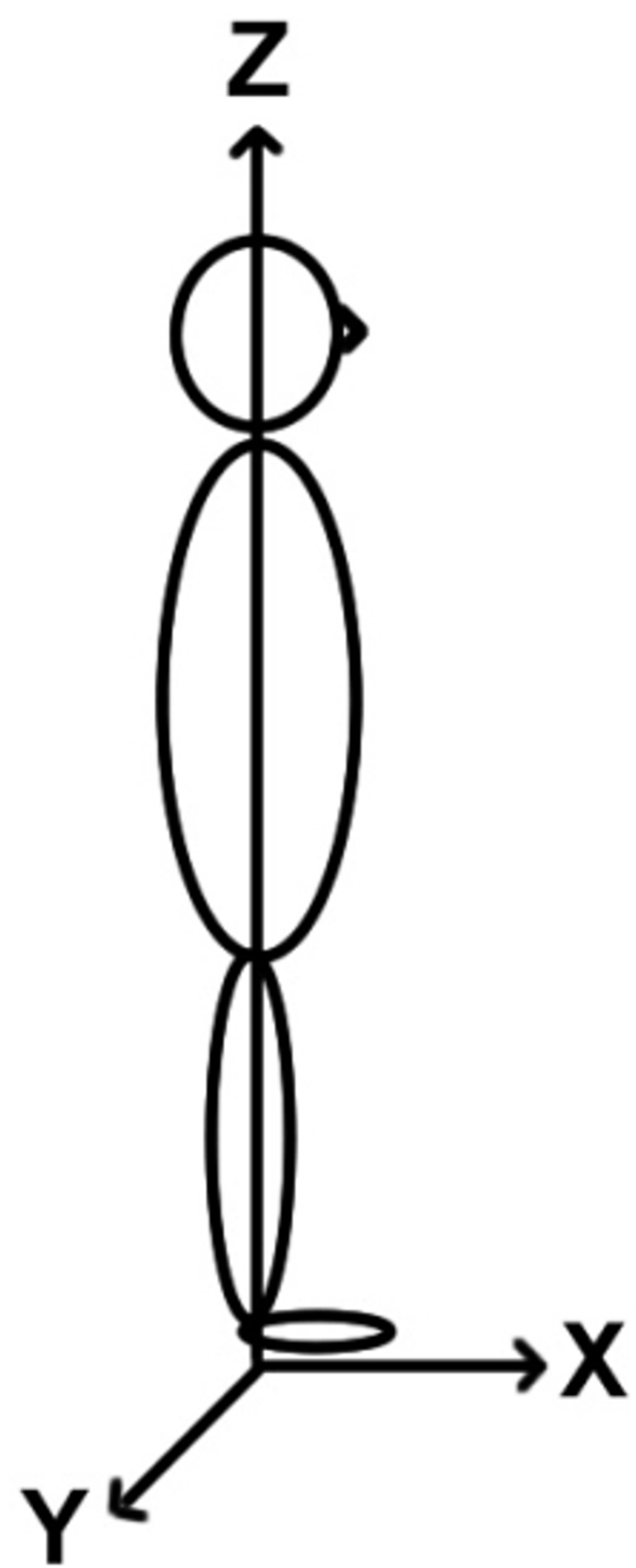

Figure I

Description of the axis definitions used in the study. The positive $x$ direction was the forward orientation, the positive $y$ direction was the rightward orientation, and the positive $z$ direction was the upward orientation 
way [63] where propioceptive stimuli from both the skin and the joint are activated [64]. The clinical testing was done using passive inversion and active rotation of each foot. The effect of the stretch procedures was evaluated using standard methods of Applied Kinesiology (AK) as described elsewhere $[65,66]$. In this context, the propioceptive provocation can elicit a so-called therapy localization (TL) which provokes a change in muscle tonicity as documented by EMG analysis [67]. The change in muscle tonicity can be evidenced by the manual examination [68]. The response pattern can thus be reduced to binary elements, $0=$ absent, or $1=$ present. The identification of a TL site indicates a local structural change. Based on the experience gained through the investigation and treatment of the index case of this model two acupuncture points were chosen for the correction of the TL by applying acupressure on them. The points correspond to elements of the bladder and gall bladder meridians, B162 or Shen mai, and GB26 or Dai mai, respectively, which have been recently shown to be related to tendinomuscular structures by in-vivo MRI imaging of gold acupuncture needles inserted at these sites (submitted to BMC in March 2006). The examination procedure is summarized in Table 1.

Laboratory examinations included the determination of erythrocyte levels of $\mathrm{Zn}, \mathrm{Cu}, \mathrm{Mg}, \mathrm{Ca}^{2+}, \mathrm{Na}, \mathrm{K}$, and $\mathrm{Fe}$. The determinations were carried out at a specialized laboratory (Labor Bayer, Stuttgart, Germany). In a previous study we had demonstrated that patients with thyroid disease present lower levels of Se as compared to non-thyroid disease controls (submitted to BMC, 2006). For this reason this parameter was not evaluated again in this study.

\section{Results}

\section{Description of the posture characteristics}

The visual inspection of orbital morphometry revealed several features of facial asymmetry. These changes included displacements of the inclination of the eye fissures and altered position of the eyes in the orbit as can be seen in Figs. 2, 3, 4. The evaluation of photographic material of the head revealed a head inclination in relation to the absolute vertical line ranging from $3^{\circ}$ to $12^{\circ}$, mean $5.7^{\circ}$. The inter pupillary inclination in relation to the absolute horizontal line was $2^{\circ}$ to $18^{\circ}$, mean $9.1^{\circ}$. During the observation of the gait pattern the controls showed a symmetrical foot orientation pattern whereas TAO patients did not. TAO patients presented 2 types of alteration: 1) an asymmetrical step pattern with one foot oriented outwards, i.e. $\mathrm{Y}_{+}$, raging from $18^{\circ}$ to $40^{\circ}$, mean $27^{\circ}$, and 2) a swinging semi-circular step pattern (not quantified) which is shown schematically in Figure 5. In the unsupported supine position the foot angle orientation was asymmetrical in all TAO patients having one dominant side, i.e. the same one having the $\mathrm{Y}+$ deviation during gait. The foot angle deviation ranged from $38^{\circ}$ to $65^{\circ}$, mean $50.9^{\circ}$. Complex deviations of the foot orientation involving the $\mathrm{Y}+$ and the $\mathrm{Z}$ - direction were not quantified. These changes are shown schematically in Figure 6.

\section{Description of the functional testing}

Using the propioceptive stretch stimulus on the feet, i.e. passive inversion, a TL reaction was seen in 4 of 16 controls and in 11 of 13 TAO patients. Active rotation of the feet (Figure 7) was positive in 3 of 16 controls and in 12 of 13 TAO patients. The finding of a positive TL was independent from the measured degree of axial displacement of the feet. Active rotation of the ankle was accompanied by a snapping sound of the joint in all TAO patients. In addition 5 out of 13 TAO patients presented an involuntary movement of the toes of the contra lateral foot being tested during foot rotation. The TL effect of these stimuli could be eliminated by gentle acupressure of 2 seconds duration on the pre-selected acupuncture points. The TL arising from passive foot inversion was neutralized in $90 \%$ of cases by the Dai mai point or Gb26 (lateral abdomen), while the foot rotation TL was neutralized mostly by the Shen mai point or Bl62 (lateral ankle), even in the cases presenting the moving toes. The correction pattern was applicable to both controls and patients.

Table I: Outline of the WOMED clinical examination protocol

\begin{tabular}{lll}
\hline Position & Parameter & Characteristics \\
\hline Sitting or standing & $\begin{array}{l}\text { Eyes in orbit } \\
\text { Orbit on head } \\
\text { Head on neck } \\
\text { Neck on trunk } \\
\text { Hip }\end{array}$ & $\begin{array}{l}\text { Symmetry, angular displacement } \\
\text { Symmetry, angular displacement } \\
\text { Rotation, tilting } \\
\text { Rotation, tilting, tender points } \\
\text { Standing }\end{array}$ \\
\hline Unloaded supine position & Leg axis & Medio lateral height symmetry \\
& Feet on shank & Symmetrical position, axial rotation \\
Functional propioceptive & Foot inversion & Extension, inversion \\
test & Foot rotation & Changes in the test muscle \\
\hline
\end{tabular}




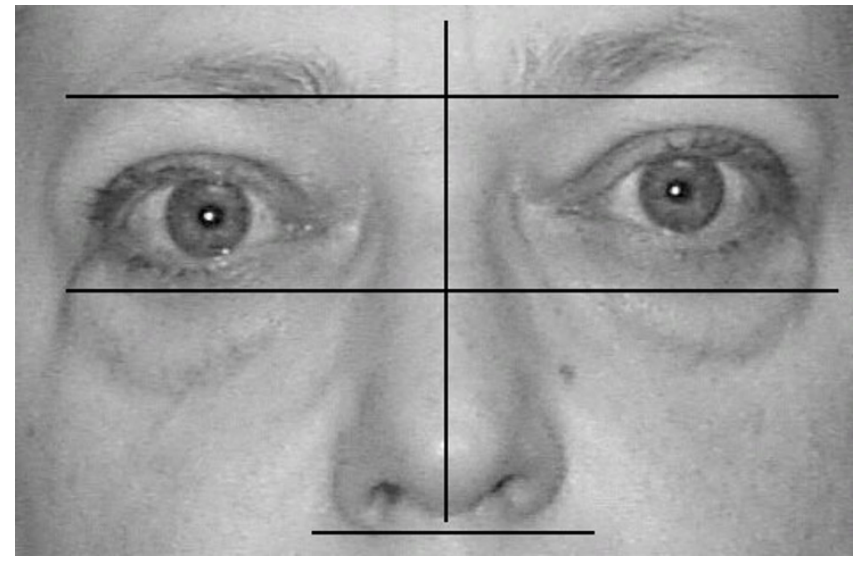

Figure 2

A TAO patient showing moderate changes in facial symmetry. Misalignments of the eyes on the orbit and of the orbit on the head are noted.

\section{Analysis of the biochemical parameters}

The biochemical parameters showed a diminution of the erythrocyte levels of $\mathrm{Zn}(\mathrm{p}=0.05)$ and an increased $\mathrm{Cu}$ to $Z n$ ratio $(\mathrm{p}<0.05)$ (Table 2$)$. The controls showed a negative correlation between $\mathrm{Ca}^{2+}$ and $\mathrm{Mg}$ and a positive correlation between $\mathrm{Mg}$ and $\mathrm{Fe}$. In the TAO patients these correlations had changed. TAO patients showed a direct correlation between $\mathrm{Ca}^{2+}$ and $\mathrm{Cu}$ while Fe was negatively correlated with $\mathrm{Ca}^{2+}$ and $\mathrm{Cu}$ (Table 3 ). The negative correlation between $\mathrm{Mg}$ and $\mathrm{Ca}^{2+}$ was not found in TAO patients.

\section{Discussion}

Based on the close relation between vision and posture control $[51,52]$ we hypothesized that elements related to biomechanical features of posture and gait could be present in TAO patients and that such changes could be related to a low grade systemic inflammation $[3,38]$. In this study we have been able to show that TAO patients present facial asymmetry with deviation of the interpupillary axis as well as of the head-on-neck position (Figures 8,9$)$ together with axial rotation of the legs and feet. Active foot rotation was found to be coupled to an altered neurological response producing the phenomenon of moving toes in the contra-lateral foot. Until now, moving toes have only been described in neurological patients [69-73]. Due to the lack of a resting phase in the contra lateral foot, one can expect that propioceptive stimuli produce altered signals in the brain, thus affecting the areas involved in their coordination $[74,75]$. This feature is new in TAO.

In addition to the moving toes phenomenon, active foot rotation or foot inversion were associated with an altered

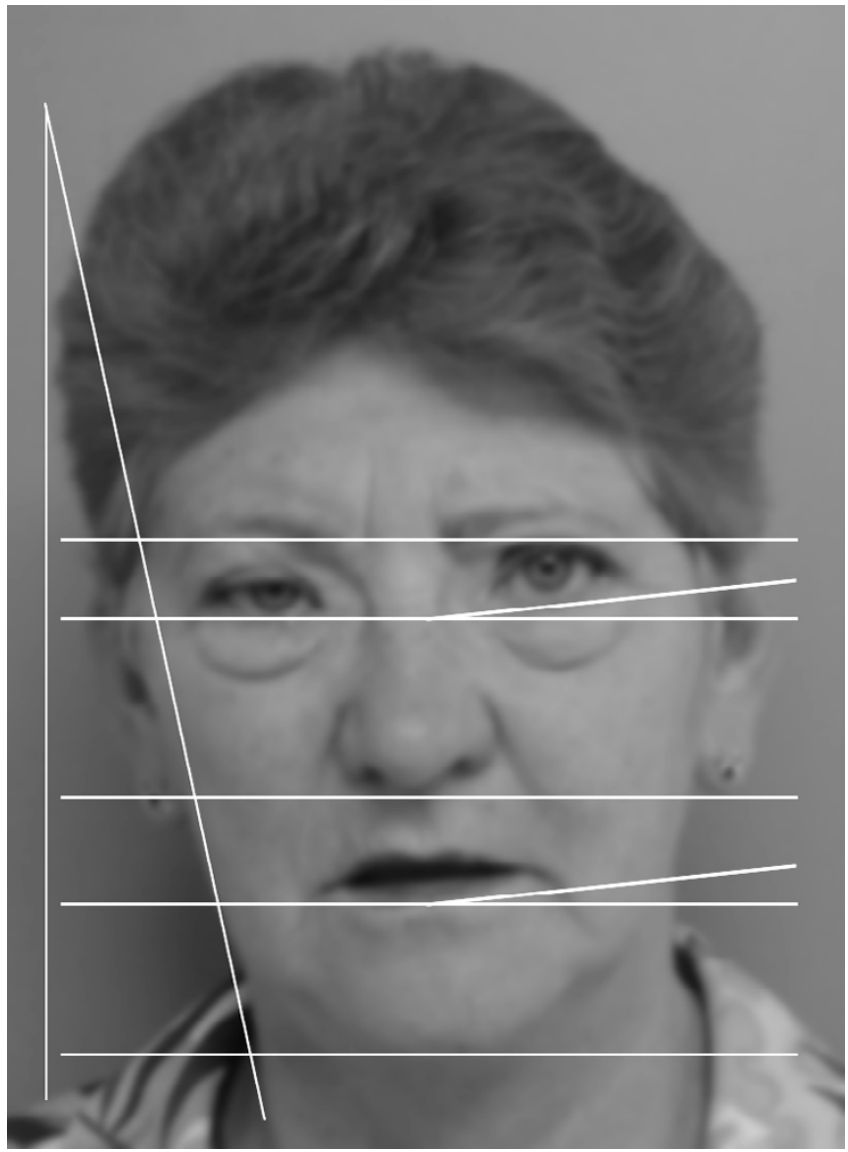

Figure 3

A TAO patient showing complex changes of facial symmetry. These include $\mathrm{Y}+$ changes in the head on neck position, of the orbital axes as well as on the alignment of the eyes on the orbit.

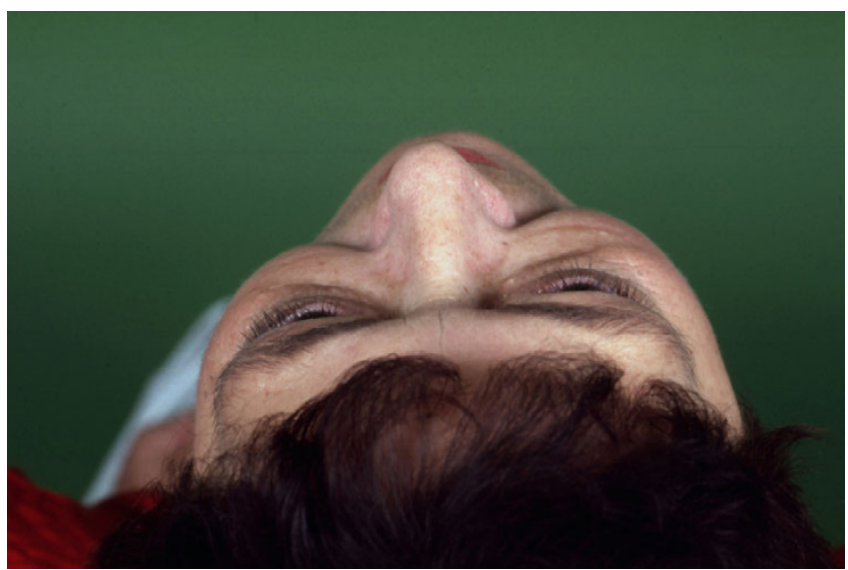

Figure 4

TAO patient showing left rotation the orbits and head as seen by photographic documentation taken from above. 


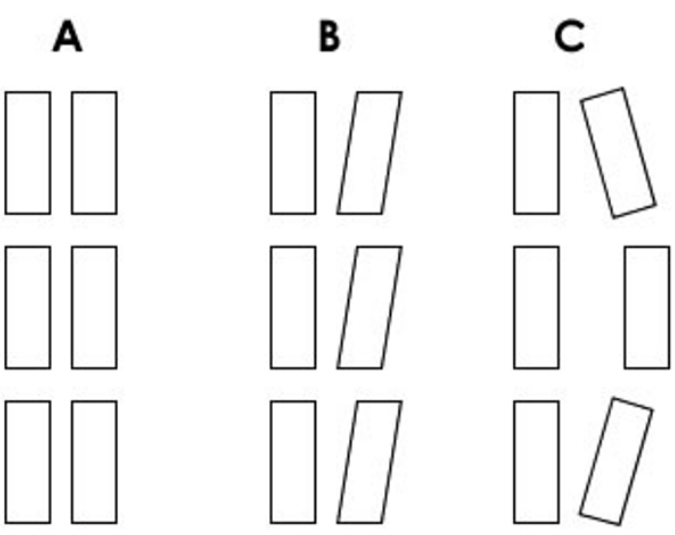

\section{Figure 5}

Description of the foot orientation patterns observed during gait. The left panel shows a symmetrical gait. The middle panel shows a lateral foot deviation. The right panel signalizes a rotating, semicircular pattern of foot advancement.

propioceptive response during manual examination which could be compensated by using acupressure on 2 specific acupuncture points. The manual examination procedure constitutes a simple binary evaluation approach where either altered musculoskeletal regulation is found or not. Based on our results we propose that TAO patients present alterations of whole body axial changes as shown in Figure 10. The most complex situation of axial misalignment resembles an arch-type body posture which we have called lateral tension. This term represents the eccentric muscle positions of the foot and leg, as well as that of the neck muscles due to a contra-lateral head tilt (Figure 11). Recent publications by the group of Milias et al. $[76,77]$ include a photograph of normal subject that presents the typical outward rotation of the foot as we describe here. These studies were centered on the actions of Se on muscle function tests and included dynamometric analysis. This postural alteration, however, was not characterized by the authors. Literature evidence on the potential interactions of these musculoskeletal changes on posture is summarized in Table 4.

On the biochemical side, our study has confirmed the finding of diminished erythrocyte $\mathrm{Zn}$ levels in hyperthyroidism $[78,79]$. Zinc plays an important role in the maintenance of multiple body functions. One general function is that of providing site-specific antioxidative protection together with Se [80]. In a recent study we have also demonstrated that patients with thyroid disease have diminished levels of Se (submitted to BMC, 2006). We will mention some aspects that appear relevant to TAO. Low erythrocyte levels of $\mathrm{Zn}$ are characteristic of hyperthyroidism and not of subacute thyroiditis [81], thus suggesting that different pathogenetic mechanisms are involved in these entities. $\mathrm{Zn}$ availability is a key factor for the development and function of the immune system [8284]. Fraker et al. have pointed out the importance of $\mathrm{Zn}$ supplementation in order to overcome "the dismantling of the immune system" [85]. Studies on TAO have seldom considered $\mathrm{Zn}$ even though it is an important regulator of retinal function [86-88]. Neuritis of the optic nerve has also been described as being associated with low $\mathrm{Zn}$ levels [89]. Smoking, which is a known risk factor for TAO $[90,91]$, can lead to diminished $\mathrm{Zn}$ levels in serum [92]. Muscle and tendon function are also related to $\mathrm{Zn}$. $\mathrm{Zn}$ uptake has been located to the connective tissue space of muscle [93]. Lack of $\mathrm{Zn}$ could diminish collagenase activity leading to a hardening of tendon tissue resulting in the characteristic snapping we have documented. Regarding the other biochemical parameters, we have not found any studies that have analyzed erythrocyte $\mathrm{Ca} 2+$ and $\mathrm{Mg}$ levels

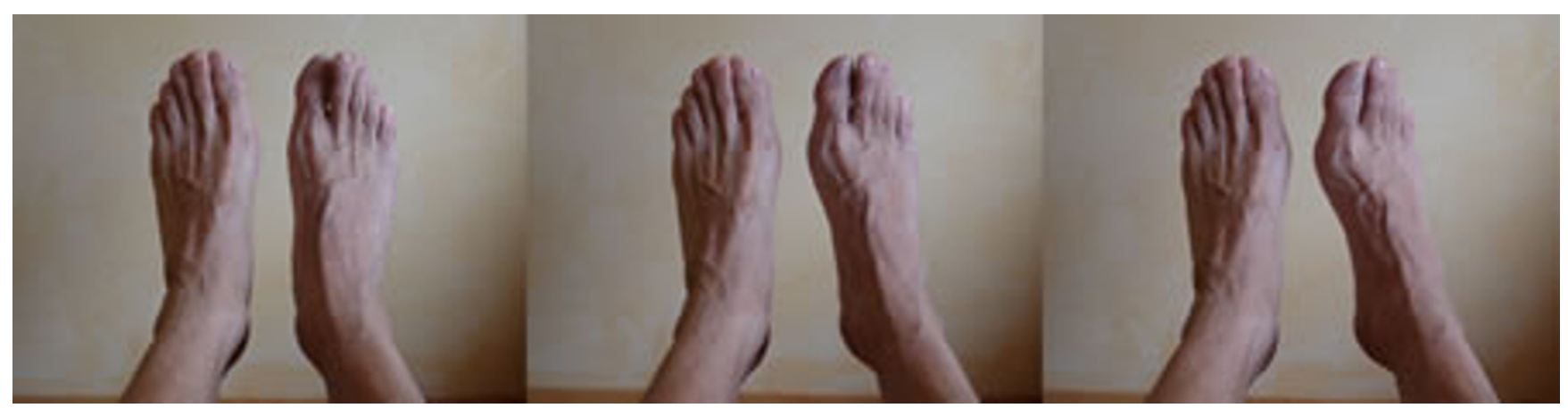

Figure 6

Description of the changes in foot alignment while lying supine in an unloaded position. The left panel shows a symmetrical position. The middle panel shows a slight displacement of the $Y$ axis. The right panel shows a more pronounced displacement of the foot in the $Y$ axis corresponding to inversion. 


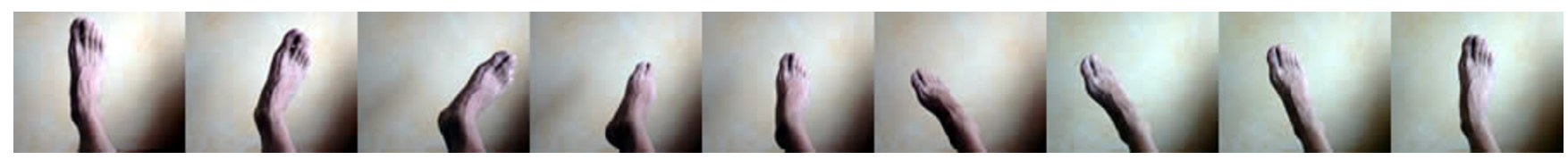

Figure 7

Description of the foot rotation test by which several muscle groups are activated. Besides the muscle activation propioceptive stimuli arise from skin and tendon stretching.

in TAO patients. Further implications of these findings will be discussed below.

The scientific literature has abundant data on biomechanical evaluations of gait and posture, but none has been carried out in TAO patients. In the majority of studies, normal subjects restricted through the use of a bracing apparatus have been evaluated. Under these conditions, the innate posture cannot be characterized. Quantitative approaches, i.e. dynamometry, have revealed that muscle strength is diminished in patients with hyperthyroidism. In spite of having quantitative data on muscle strength, these studies [16-18] have not attempted to derive corrective procedures as we have done. A beneficial role of muscle strength for the prevention of falls was mentioned by Brennan [16]. We will comment on this in the outlook section.

The description of new features of TAO patients arising from this study is a consequence of the philosophy of our Institution WOMED. Here we are committed to deliver an integral approach to disease in each individual. Within this frame we have previously described therapeutical measures for treating periorbital edema in TAO [67] or daily stress burden in hyperthyroidism [94]. For this reason, we have chosen to call our results and observations the WOMED concept of lateral tension. This concept includes components of musculoskeletal function, endocrine function, and nutrition.

The following discussion will expand to deal with the following topics: 1) muscle involvement in Graves' disease and TAO, 2) effects of eccentric muscle action on muscle inflammation, 3) calsequestrin and the $\mathrm{Ca}^{2+}$ regulation system, 4) involvement of the connective tissue and superoxide dismutase (SOD), 5) propioception and biomechanical implications, 6) functional imaging data in relation to the model, and 7) summary of the WOMED concept of lateral tension in the context of inflammation and IL- 6 .

\section{I) Muscle involvement in Graves' disease and TAO}

On clinical grounds, thyroid disease can be found to be associated with musculoskeletal components such as with polymyositis [35,36], eosinophilic fasciitis [37], as well as with myalgia and swelling of the calves and fasciitis [31]. Recent investigations have found an increased peripheral glucose utilization, i.e. ${ }^{18}$ F-fluorodeoxyglucose uptake in the muscles of patients with Graves' disease [46]. Increased peripheral glucose metabolism can signalize inflammatory changes [47]. Finally, indirect evidence on the presence of inflammation in muscles of TAO patients, e.g. neck muscles [50] and shank [49] (Figure 12), can be seen through the use of radioactive labeled octreotide, a somatostatin analog which can depict immunological or

Table 2: Comparison of erythrocyte mineral and metal levels

\begin{tabular}{|c|c|c|c|c|c|c|c|}
\hline Study Groups & & $\mathrm{Ca}$ & Mg & $\mathbf{Z n} *$ & $\mathrm{Cu}$ & Mg Ca ratio & Cu Zn ratio** \\
\hline \multirow[t]{5}{*}{ TAO patients } & $\mathrm{n}$ & 13 & 13 & 13 & 13 & 13 & 13 \\
\hline & Mean & 60,78 & 33,82 & 6,75 & 1,42 & 0,56 & 0,22 \\
\hline & S.D. & 3,11 & 2,31 & 1,22 & 0,48 & 0,04 & 0,08 \\
\hline & $\min$. & 56,89 & 30,14 & 4,30 & 1,02 & 0,50 & 0,13 \\
\hline & $\max$ & 68,65 & 37,29 & 8,57 & 2,82 & 0,62 & 0,40 \\
\hline \multirow{5}{*}{$\begin{array}{l}\text { Normal } \\
\text { controls }\end{array}$} & $\mathrm{n}$ & 16 & 16 & 16 & 16 & 16 & 16 \\
\hline & mean & 60,73 & 33,41 & 7,41 & 1,25 & 0,55 & 0,17 \\
\hline & S.D. & 1,83 & 3,01 & 0,46 & 0,32 & 0,06 & 0,04 \\
\hline & $\min$ & 56,70 & 29,19 & 6,40 & 0,90 & 0,47 & 0,12 \\
\hline & $\max$. & 64,45 & 38,14 & 8,17 & 1,96 & 0,67 & 0,27 \\
\hline
\end{tabular}

\footnotetext{
$* \mathrm{p}=0.05, * * \mathrm{p}<0.05$
} 
Table 3: Correlation analysis of $\mathrm{Zn}, \mathrm{Ca}, \mathrm{Mg}$ and $\mathrm{Cu}$ levels

\begin{tabular}{|c|c|c|c|c|c|c|}
\hline & & & $\mathrm{Mg}$ & $\mathrm{Cu}$ & $\mathrm{Zn}$ & $\mathrm{Fe}$ \\
\hline \multirow[t]{12}{*}{ TAO } & $\mathrm{Ca}$ & $r$ & 0,239 & $0,64 I^{*}$ & $-0,060$ & $-0,758 * *$ \\
\hline & & $\mathrm{P}$ & 0,432 & 0,018 & 0,845 & 0,004 \\
\hline & & $\mathrm{n}$ & 13 & 13 & 13 & 12 \\
\hline & $\mathrm{Mg}$ & $r$ & & $-0,042$ & 0,121 & 0,125 \\
\hline & & $p$ & & 0,892 & 0,693 & 0,699 \\
\hline & & $n$ & & 13 & 13 & 12 \\
\hline & $\mathrm{Cu}$ & $r$ & & & 0,116 & $-0,663^{*}$ \\
\hline & & $\mathrm{P}$ & & & 0,706 & 0,019 \\
\hline & & $n$ & & & 13 & 12 \\
\hline & $\mathrm{Zn}$ & $r$ & & & & $-0,165$ \\
\hline & & $\mathrm{P}$ & & & & 0,609 \\
\hline & & $n$ & & & & 12 \\
\hline \multirow[t]{12}{*}{ Controls } & $\mathrm{Ca}$ & $r$ & $-0,632^{* *}$ & 0,357 & $-0,085$ & $-0,485$ \\
\hline & & $P$ & 0,009 & 0,175 & 0,756 & 0,057 \\
\hline & & $\mathrm{n}$ & 16 & 16 & 16 & 16 \\
\hline & $\mathrm{Mg}$ & $r$ & & $-0,349$ & $-0,097$ & $0,625 * *$ \\
\hline & & $p$ & & 0,186 & 0,721 & 0,010 \\
\hline & & $n$ & & 16 & 16 & 16 \\
\hline & $\mathrm{Cu}$ & $r$ & & & 0,094 & $-0,347$ \\
\hline & & $\mathrm{P}$ & & & 0,730 & 0,188 \\
\hline & & $n$ & & & 16 & 16 \\
\hline & $\mathrm{Zn}$ & $r$ & & & & $-0,277$ \\
\hline & & $P$ & & & & 0,300 \\
\hline & & $\mathrm{n}$ & & & & 16 \\
\hline
\end{tabular}

* The correlation is significant at a level of 0,05 (2-sided).

** The correlation is significant at a level of 0,01 (2-sided).

inflammatory sites in TAO [95]. Alterations of neck muscles can be viewed as being directly related to postural changes [96-99]. While previous investigations in TAO have focused on the EOM, it should be recalled that there are large differences in muscle mass between the EOM and the limb muscles. EOM have a volume of 3-5 ml $[100,101]$, while the muscle mass of the legs together with abdominal muscle can amount to $15-20 \mathrm{~kg}[102,103]$. It follows, that biochemical markers of inflammation such as GAGs $[19,20]$ are more likely to come from peripheral muscles. The postural changes we describe here correspond to an eccentric muscle action of peripheral muscles. The consequences of eccentric action will be discussed in the following section.

\section{2) Effects of eccentric muscle action on muscle inflammation}

Investigations from the field of sports medicine have provided an ample repertoire of evidence relating eccentric muscle action to muscle inflammation, cell disruption and involvement of the connective tissue [104]. Some selected aspects include the visualization of anatomical changes such as edema by means of MRI [105], the presence of WBC in muscle [106], the disruption of the cytoskeleton and myofibrils [107-109], the involvement of collagen and of collagen degrading enzymes [110,111], the involvement of tendons [112] and fasciae [113], the release of IL-6 [114], as well as the release of bradykinin and of histamine through the induction of histidine decarboxylase [115-119]. In addition to this, neuromuscular changes and dysfunction can appear [120-125]. The phenomenon of moving toes might be related to this neuromuscular dysfunction. Finally an asymmetrical body posture will influence the mechanics of the hips [126]. Figure 13 shows an extended description of the interactions of eccentric muscle action on tissue injury and repair. 


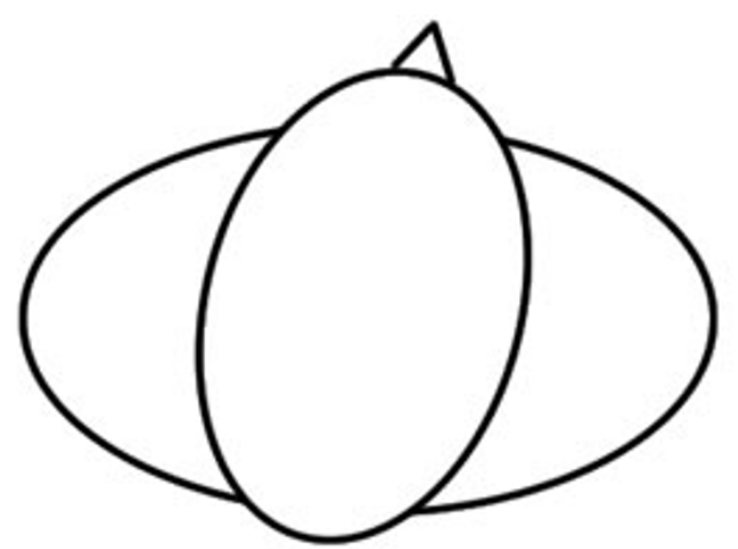

Figure 8

Schematic representation of the head on neck on trunk postural changes showing head rotation in a $Y+$ direction. Besides this rotation, lateral head tilting can also be present.

\section{3) Calsequestrin and the $\mathbf{C a 2}+$ regulation system}

In order to understand the potential impact of antibodies directed against cardiac calsequestrin (CSQ) as shown by Gopinath [40] were carried out a revision of basic and current literature dealing with $\mathrm{Ca}^{2+}$ regulation. The result of this literature analysis is summarized in Figure 14. CSQ represents only a part of the system of $\mathrm{Ca}^{2+}$ regulation. In addition to this it must be remembered that the slow type CSQ is a cardiac element and not highly specific for EOM [40]. It follows that these antibodies might be more relevant to cardiac manifestations of thyroid disease. On the other hand functional alterations of EOM do show an involvement of CSQ [127]. Modern analytical methods have documented the heterogeneity of anatomical and functional elements of EOM which makes them unique. One example involves the structural differences of the dif-
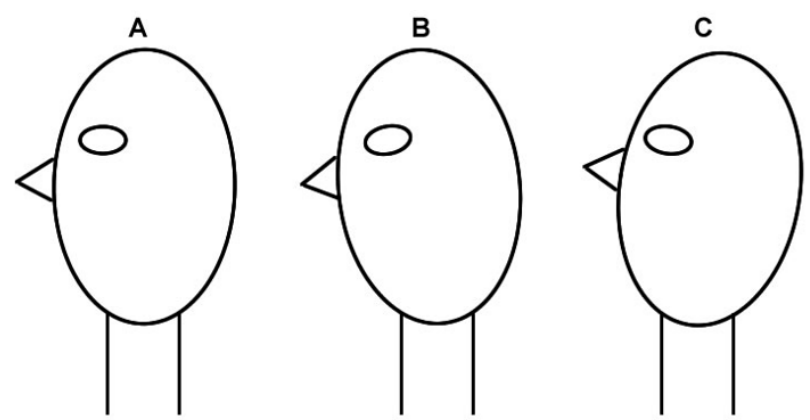

Figure 9

Schematic representation of the pitch changes of the head on neck position.
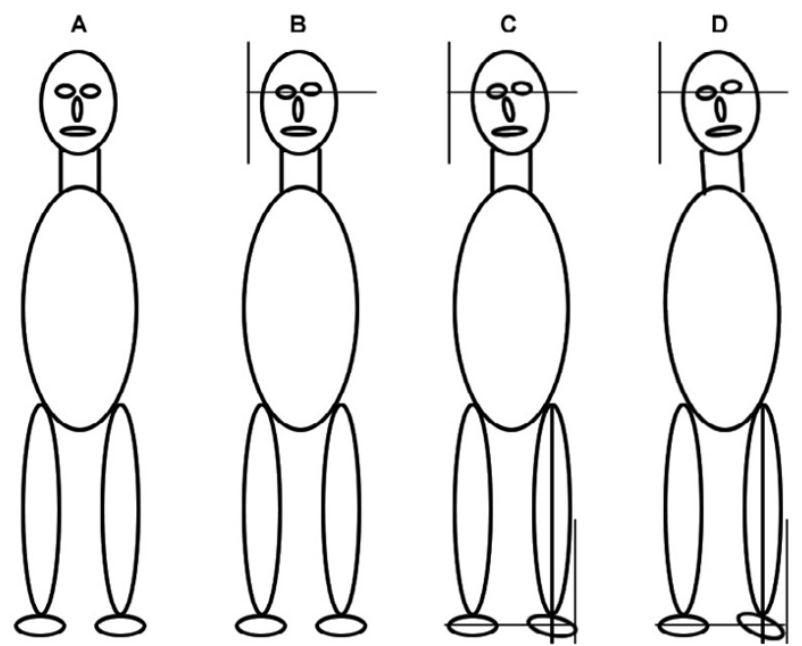

Figure 10

Schematic summary of the WOMED concept of lateral tension. The four panels describe the graded development of lateral tension. Panel $A$ shows the symmetrical body position. Panel $B$ includes only $Y+$ tilting of the head. Panel $C$ includes $Y+$ tilting, alteration of the orbits and slight eccentric position of the leg and foot. Panel D shows the complex pattern with head, orbit, face and lower limb asymmetry. We propose that in this stage eccentric muscle action will induce low grade inflammation.

ferent layers of EOM [128]. One important functional feature of EOM is that they are to be considered as tonically active muscles such as the diaphragm where function integrity depends upon the sufficient availability of antioxidant substances such as Se and SOD [129]. Another important regulator of EOM function integrity can be $\mathrm{Ca}^{2+}$ [130].

We have recently shown the importance of Se in relation to thyroid antibody levels in incipient hypothyroidism: antibodies were present when Se levels were inadequately low [131]. Once Se substitution has been implemented, thyroid antibody levels will diminish. These results are similar to those presented by Turker et al. [132]. Recently it has also been demonstrated that thyroid disease patients have lower Se levels as compared to controls (Moncayo and Moncayo, submitted to BMC, 2006). It follows that antioxidative protection can be altered in TAO. Additional interactions between $\mathrm{Ca}^{2+}, \mathrm{Se}$, and selenoproteins can occur through the ryanodine receptor as shown in Figure 14.

Interactions of $\mathrm{Ca}^{2+}$ and $\mathrm{Zn}$ are known to exist in relation to calsequestrin [133]. In relation to eccentric changes due to chronic cardiac volume overload, changes in $\mathrm{Ca}^{2+}$ and calsequestrin can result in altered contraction responsiveness to $\mathrm{Ca}^{2+}[134]$. A further relation to muscle function 


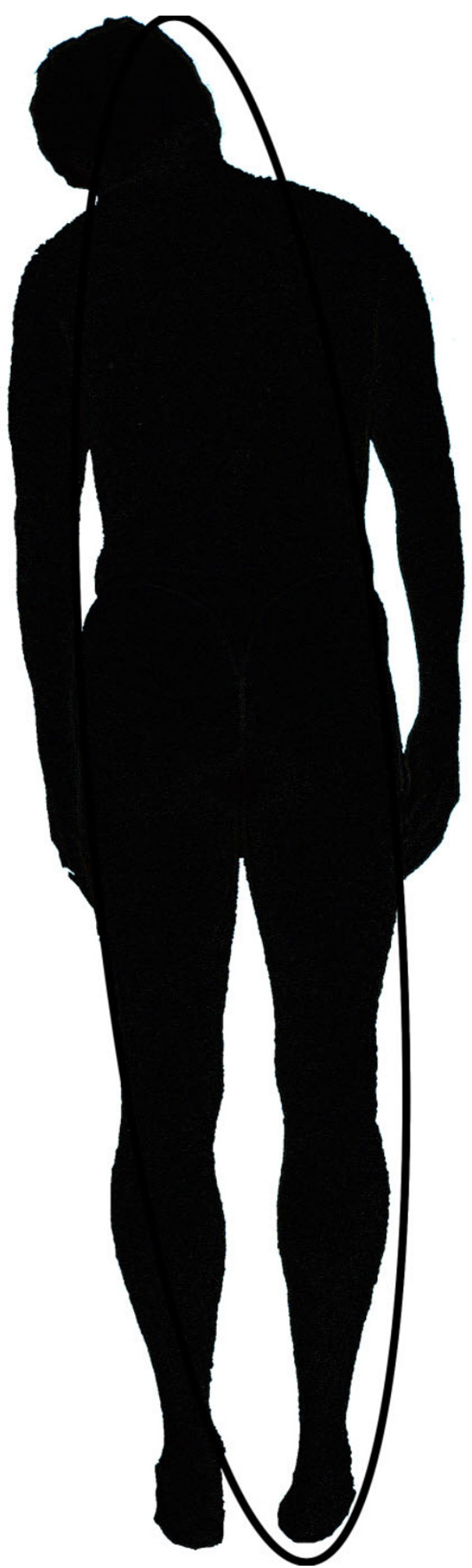

Figure I I

Simulated patient photography demonstrating the lateral tension concept. The basic elements of the model are included. can be found in the histidine-rich $\mathrm{Ca}^{2+}$-binding protein which can also bind $\mathrm{Zn}$ and is localized in the sarcoplasmic reticulum [135]. Thus it appears that the changes in the intracellular concentration of ions and metals might be affecting muscular function. Some of these relations have been described in ALS $[57,58,136,137]$

\section{4) Involvement of the connective tissue and SOD}

As described above an eccentric muscle action represents a situation of tissue damage involving muscles, tendons, fasciae and the connective tissue. Protection against these processes can be expected to come from superoxide dismutases (SOD) [138-140]. The extra-cellular SOD (ECSOD) has the capacity to bind several components of the connective tissue such as heparin, collagen and GAGs [141], some of which can be found to be altered in TAO [27]. The maintenance of functional SOD subtypes requires an adequate supply of $\mathrm{Zn}$ and $\mathrm{Cu}[142,143]$. In our patients we have not been able to measure these parameters in muscle tissue, however erythrocyte levels can be taken as a surrogate compartment [59]. In scoliosis it is known that $\mathrm{Zn}$ levels are lower in the affected muscles [144]. Thus, the same might happen in TAO. We can only speculate that the functions of SOD might be influenced by the shift of ions and metals we have found as is known in amyotrophic lateral sclerosis (ALS). Zn deficiency can alter the SOD so that it can be neurotoxic locally [145]. Extrapolating from experimental data neurotoxicity could affect elements involved in inhibitory regulation of neural function such as the spinal cord $[146,147]$ or cerebellar cortex [148]. In turn, cerebellar structures are involved in muscle action and coordinated muscle action [149-151]. Our finding of moving toes in TAO patients could correspond to a situation of lack of spinal cord inhibition.

\section{5) Propioception of the lower extremity and general biomechanical implications}

Considering that mechanical test procedures for ankle stability are liable to problems [152] we chose to use a simple manual test for the evaluation of ankle mobility based on principles of Applied Kinesiology. Dedicated research centers utilize electromagnetic devices for a similar purpose [153]. Guralnik et al., using a small battery of functional tests, have shown that lower extremity function is an important parameter for the prediction of disability in later years [154]. Within this field of prediction of disability-related problems, clinical investigations should attempt to detect alterations and implement correction measures. Our simple manual method has the advantage that once a TL has been found, the effectiveness of a correction step can be evaluated. In our study the use of acupressure on the lateral side of the abdomen or of the ankle was enough for reversing this propioceptive stimulus. Based on the observations of Roll and collaborators referring to the interactions between the dynamometric map 
function of the feet and posture regulation $[155,156]$ we can corroborate this notion. Tension transmission along the foot, ankle and lower limb to the trunk belong to our WOMED concept of lateral tension (Figure 11). Tension transmission is based on the principle of fascia and fascial continuity [157]. More importantly in 1989 Roll, Vedel and Roll described the intricate relation between the retroocular muscles and posture control [55]. Lack of ankle function in relation to posture might be an important factor in the tendency to fall which turns to be a matter of serious concern in older patients. Analytical studies have revealed the importance of gait variability in relation to stride width [158]. Others have emphasized that all ankle motions contribute to the maintenance of gait balance [159]. Our rotational propioceptive stimulus includes all these conditions of ankle motions. In addition, neurophysiological investigations on the acupuncture points of the lateral side of the foot have shown a relation to the visual cortex $[160,161]$ thus showing complementarity to the data from Roll. Altogether, the foot and ankle appear to be important determinants of gaze, posture and gait.

The area of the trunk also plays an important role in controlling the direction of gait. As has been shown by Schmid et al. angular deviations of the foot can occur when vibrational stimuli are applied to the trunk at the level of the erector spinae muscle [62]. Trunk movements do not only involve the back; abdominal muscles are involved as well [162-164]. All of these muscular elements bear resemblance to the acupuncture meridian called girdling vessel or Dai mai vessel. Classical TCM literature attributes a holding function to this meridian. Our own imaging investigations (submitted to BMC March 2006) have led us to identify the obliquus internus muscle as the structure underlying the Dai mai point (Gb26) and the tendon of the peroneus muscle at the Shen mai point (B162). Punctual EMG analysis of these points during examination of movement should be feasible in specialized biomechanical laboratories.

\section{6) Scintigraphic imaging data in relation to the model}

We would like to highlight the diagnostic possibilities of Nuclear Medicine in the context of the model. Figure 15 shows the diagnostic capabilities of combined PET-CT scanners (in this example SIEMENS, Erlangen, Germany). The fused image, i.e. superposed PET and CT whole body images, shows metabolic activation of the left lateral shank while at the same time the right ankle also shows increased metabolic activity. We interpret this image in 2 ways. In the first place it shows the anatomical localization of the changes we describe. In the second place it demonstrates the research capabilities of whole body PETCT imaging in musculoskeletal studies with emphasis put on "whole body analysis". The image was kindly provided by Dr. David Townsend, University of Tennessee [165].
A second interesting image is one that shows increased metabolic activity in the lateral area of the abdomen [166]. These areas correspond to the Dai mai acupuncture point (see discussion in the preceding section) which is located below the free end of the 11 th rib. In addition to this, the morphological CT images also show the medio lateral displacement of the body axis (Figure 16). For clinical purposes, precise clinical evaluation of trunk deviation can be carried out by rasterstereography [167].

Besides the examples given here, we would like to stress the applicability of whole body ${ }^{18} \mathrm{~F}$-Fluorodeoxyglucose imaging as an investigational tool to characterize whole body muscle activity in vivo [168-176] or even tendon activity [177]. In a whole body approach both agonistic and antagonistic muscle groups can be evaluated and a metabolic quantification can be done.

\section{The WOMED concept of lateral tension, inflammation and IL-6}

The WOMED concept of medical care can be summarized as an integral care of the individual. Within this concept elements of TCM and Western medicine are intermingled. Some of the evaluation parameters used in each patient are posture, locomotion, structural cohesion, previous infectious diseases, nutrition habits, nutritional status, internal medicine evaluation, and gynecological evaluation when needed. In addition to this both endocrinological and immunological aspects are included. Examples of this medical approach have been published $[67,94,131]$.

Our interpretation of lateral tension involves eccentric muscle action. Due to the contained structure of the orbit with limited expansion, it does not appear plausible that the initial lesion occurs here. On the other hand, due to the frequent involvement of the ankle in daily lesions [178-180] it seems plausible that the initial pathogenic stimulus arises from this area. In addition to lesions of the lower limb, postural problems are not seldom found even in young children [181]. Therefore pre-existing postural changes together with low grade eccentric action could have a negative effect on the musculoskeletal system leading to a low grade inflammation which can also lead to consumption of vital resources such as Se and Zn. Lack of antioxidants will give way to an elevation of IL-6 [182]. The role of IL- 6 in muscle metabolism has been matter of intense investigation over the past years. IL- 6 appears to have several effects on the muscle and appears to play a role in the control of normal muscle function [183]. Activation of muscular IL-6 release depends also on glycogen levels [184], as well as on the interplay of $\mathrm{Ca}^{2+}[185]$. Repetitive low force exercise can also lead to increased interstitial concentrations of IL-6 [186]. The area surrounding the Achilles tendon can be taken as an example for changes seen in eccentric exercise and can be character- 
Table 4: Postural changes observed in TAO patients and implications of these changes

\begin{tabular}{|c|c|c|c|c|}
\hline Basic structure & Related organ & Description of the alteration & Axes & Potential effects \\
\hline \multirow[t]{4}{*}{ Head } & Eyes & Elevation, tilted & $X, Y, Z$ & postural alignment $[196,197]$ \\
\hline & Neck & Rotated, tilted, extended or flexed & $\mathrm{X}, \mathrm{Y}, \mathrm{Z}$ & dorsal muscles [198] ocular torticolis $[96,97]$ \\
\hline & Nose & Tilted & $\mathrm{Y}, \mathrm{Z}$ & Retro nasal space? \\
\hline & Mouth & Tilted & Y & Jaw [199] \\
\hline Face & & Asymmetry & & Head holding [200] \\
\hline Neck & Trunk & Rotated & $Y$ & Lymphatics, posture $[200,201]$ \\
\hline Trunk and abdomen & & $\begin{array}{l}\text { Rotated Increase of the intra- } \\
\text { abdominal pressure }\end{array}$ & Y & Foot angle [62] Pelvic girdle pain [202] \\
\hline Leg & Pelvis Gluteus m. & Rotated & Y & $\begin{array}{l}\text { Hip sway Transversus abdominis [190] Altered } \\
\text { femoral control [203] }\end{array}$ \\
\hline Ankle & Shank Hip & Reduced range of motion & $\mathrm{X}, \mathrm{Y}, \mathrm{Z}$ & $\begin{array}{l}\text { Instability [204], Sway Sensory changes and } \\
\text { hypermobility [205,206] Altered hip load - unload } \\
\text { [126] Hip weakness [207] }\end{array}$ \\
\hline Feet & shank & Lateral displacement & $\mathrm{Y}, \mathrm{Z}$ & Tightness of lateral calf muscles [I56] \\
\hline Feet & Sole & Asymmetry & $Y$ & $\begin{array}{l}\text { Posture information [155] Influence on retroocular } \\
\text { muscles [55] }\end{array}$ \\
\hline Foot to head & Whole body & & & Posture asymmetry [208] \\
\hline
\end{tabular}

ized by means of microdialysis studies [186-188]. This type of investigations can provide an anatomically close view of the changes that can occur. Inflammatory reactions can indeed be found by this method even when there are no apparent changes in blood [186-188]. A graphical summary of mechanisms of inflammation is given in Figure 17 pointing out the relevance of Se. Further vinculations to insulin resistance, as a part of the socalled metabolic syndrome, are also included.

The lateral tension model bears resemblance to the biomechanical five segment model of Levin et al. [189] where the feet, the legs and the abdomen are viewed as a unit. Our study has shown that the use of acupressure on the lateral abdomen normalized the TL produced by the stretch stimulus thus suggesting an important role of it for posture. Biomechanical observations have shown that a primary activation of these muscles occurs during gait [190] and that these muscles influence the mechanics and the tension of the back $[191,192]$. Altered foot positioning, as we have found here, can also be produced by muscle stimulation from the back [62]. This underlines the functional relationships of the ankle and trunk in locomotion [189]. The Dai mai point, located at the lateral abdomen, can be considered to be a trigger point [193] that represents the existing biomechanical tension arising from eccentric exercise. Tension will lead to taut band formation and this can be found by manual examination.

\section{Conclusion}

The WOMED concept of lateral tension which is centered around the abdominal muscles might be applicable to other conditions of musculoskeletal diseases. It is important to point out that our proposed use of acupuncture to treat fascial changes in the WOMED model of lateral ten- sion coincides with the expectations from Shah et al. [187]. They propose the used of microdialysis needles as surrogates for acupuncture needles to treat myofascial trigger points. By our means of manual clinical investigation, relevant myofascial trigger points can be found easily. For analytical scientific research procedures such as dynamometry, body surface scanning, and in-vivo microdialysis will provide figures and numbers related to our model. It can be expected that 2D separation of serum proteins will allow a closer insight into the changes in the proteome in selected diseases [194]. Our clinical experience in patients with TAO, multiple sclerosis, fibromyalgia and similar conditions suggests that successful treatment can rely on acupuncture techniques that aim at correcting the integration of neurophysiological inputs.

\section{Simple but relevant quotes}

We are involved with musculoskeletal function every day and take it for granted. For this reason every day use might not appear to be relevant to disease in the first place. Terry F. Davies, Editor in Chief of Thyroid, has made reference to this situation while commenting on the pathogenesis of TAO: "It maybe very well be true that there is nothing new under the sun - it is just that we have either forgotten it or never understood it" [195]. While this applies to daily motor accomplishments, unusual musculoskeletal exercise with repetitive eccentric muscle action can produce an acute situation similar to the one we describe. The impressions of Lance Armstrong after the N.Y. marathon in November 2006 illustrates this: "Even after experiencing one of the hardest days of the Tour nothing has ever left me feeling this bad," he said at a post-race news conference. " [My shins] started to hurt in the second half, but the bigger problem the last 7 or 8 miles was the tightness in my calves and thighs. My calves really knotted up. I can 


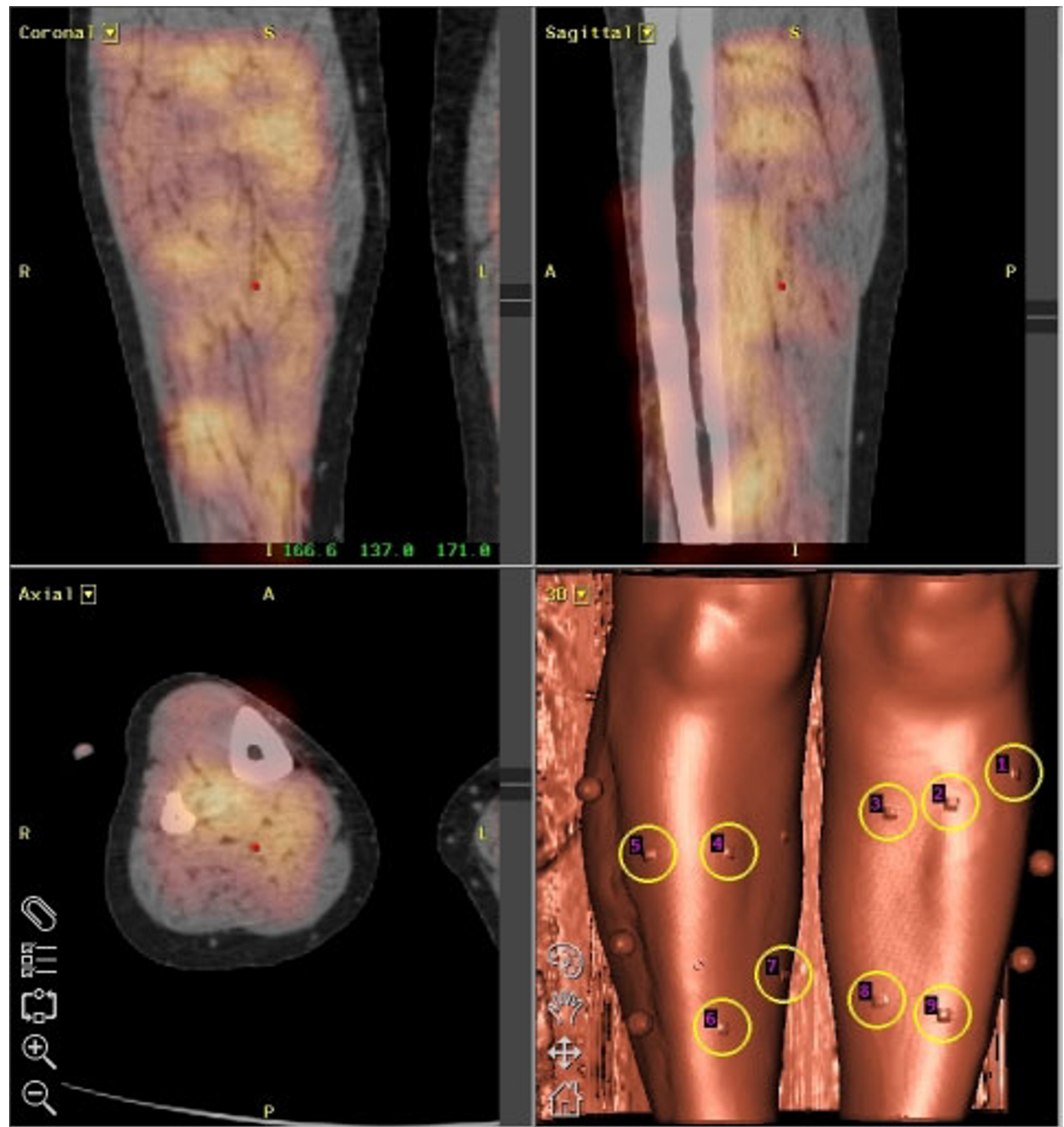

\section{Figure 12}

Image fusion of CT and scintigraphic data showing diffuse Octreotide uptake in the lower limbs of a patient with TAO. Octreotide uptake represents inflammatory activity. Taken from [49]. Each reconstruction plane is labeled in the upper left corner of the image. The right lower image is an anatomical reconstruction of the surface of the leg.

barely walk right now." Figure 18 presents a graphical summary of the model together with potential every day stressors such as bicycle riding and running.

\section{Competing interests}

The author(s) declare that they have no competing interests. 


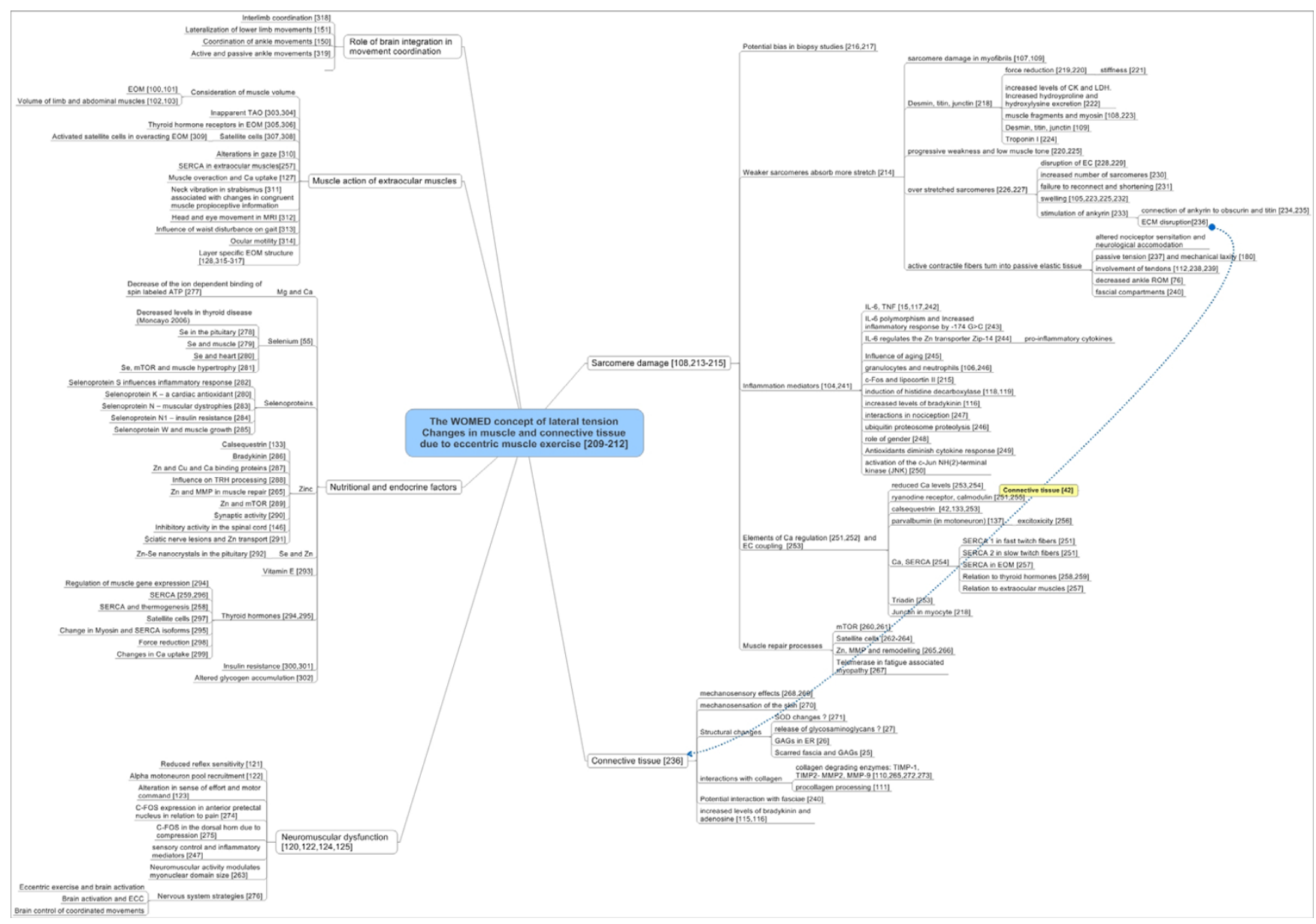

Figure 13

Graphical summary of relevant scientific data related to the effects of eccentric muscle action. The images recollect physiological data as well as nutritional and endocrine aspects. Emphasis is put on the roles of $\mathrm{Zn}$ and Se.

\section{Authors' contributions}

RM and HM contributed equally to the development of the concepts of this work. RM did the art work and the Mind Maps. All authors read and approved the final manuscript.

\section{Note}

The WOMED concept of lateral tension Changes in muscle and connective tissue due to eccentric muscle exercise [209-212]

\section{Sarcomere damage $[108,213-215]$}

1.1 Potential bias in biopsy studies $[216,217]$

1.2 Weaker sarcomeres absorb more stretch [214]
1.2.1 sarcomere damage in myofibrils $[107,109]$

1.2.2 Desmin, titin, junctin [218]

force reduction $[219,220]$

stiffness [221]

increased levels of CK and LDH. Increased hydroyproline and hydroxylysine excretion [222]

muscle fragments and myosin $[108,223]$

Desmin, titin, junctin [109]

Troponin I [224] 


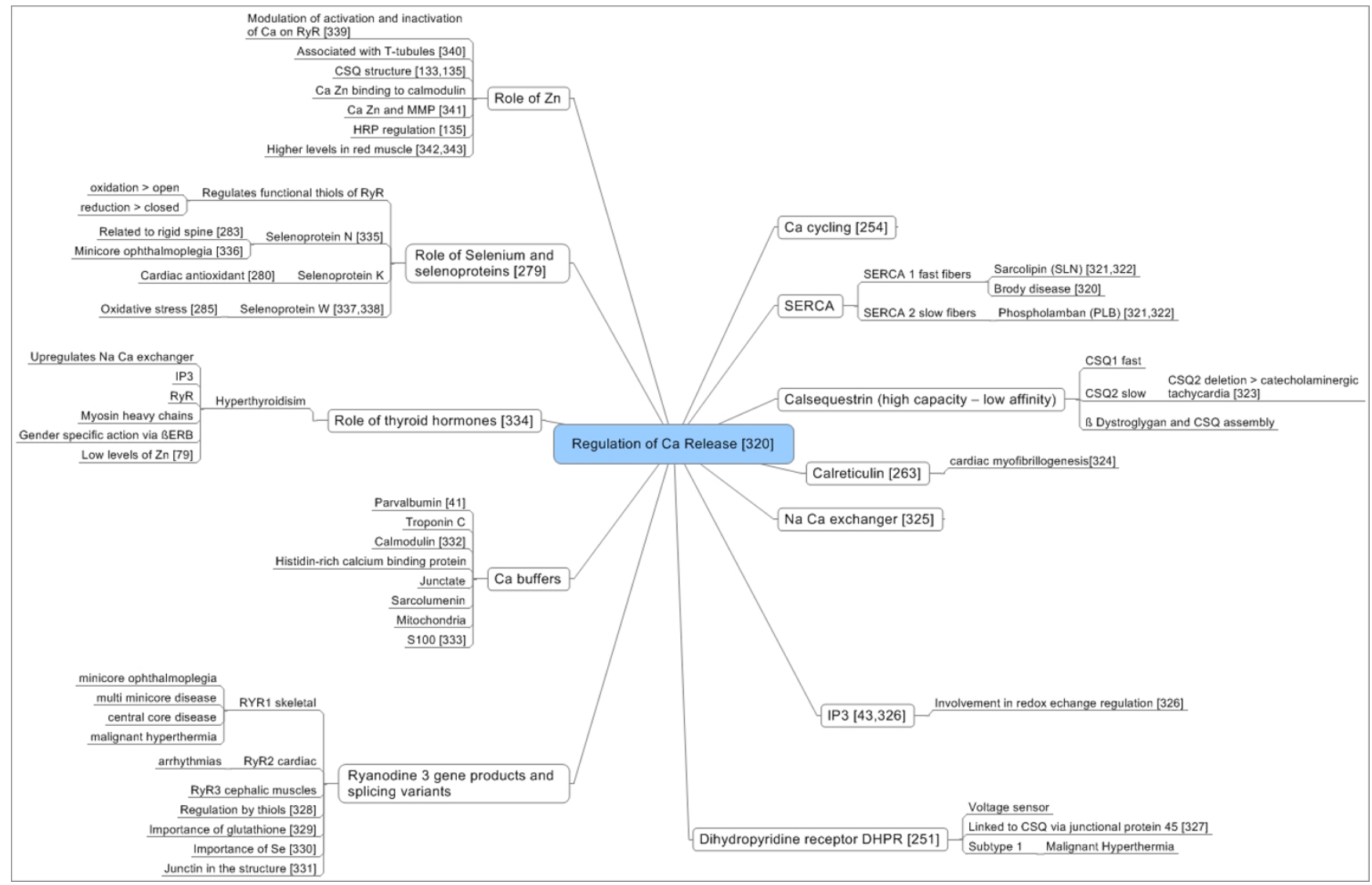

\section{Figure I4}

Graphical summary of relevant scientific data related to Ca regulation. Ca regulation has been suggested to be important in TAO. This assumption is based on the finding of antibodies directed against calsequestrin [40,370]. Interactions with $\mathrm{Zn}$ and Se are included.

1.2.3 progressive weakness and low muscle tone $[220,225]$

1.2.4 over stretched sarcomeres [226,227]

disruption of EC [228,229]

increased number of sarcomeres [230]

failure to reconnect and shortening [231]

swelling [105,223,225,232]

stimulation of ankyrin [233]

connection of ankyrin to obscurin and titin [234,235]

ECM disruption[236]

Siehe auch: Connective tissue[42]
1.2.5 active contractile fibers turn into passive elastic tissue

altered nociceptor sensitation and neurological accomodation

passive tension [237] and mechanical laxity [180]

involvement of tendons [112,238,239]

decreased ankle ROM [76]

fascial compartments [240]

1.3 Inflammation mediators [104,241]

\subsubsection{IL-6, TNF $[15,117,242]$}

1.3.2 IL-6 polymorphism and Increased inflammatory response by $-174 \mathrm{G}>\mathrm{C}$ [243] 


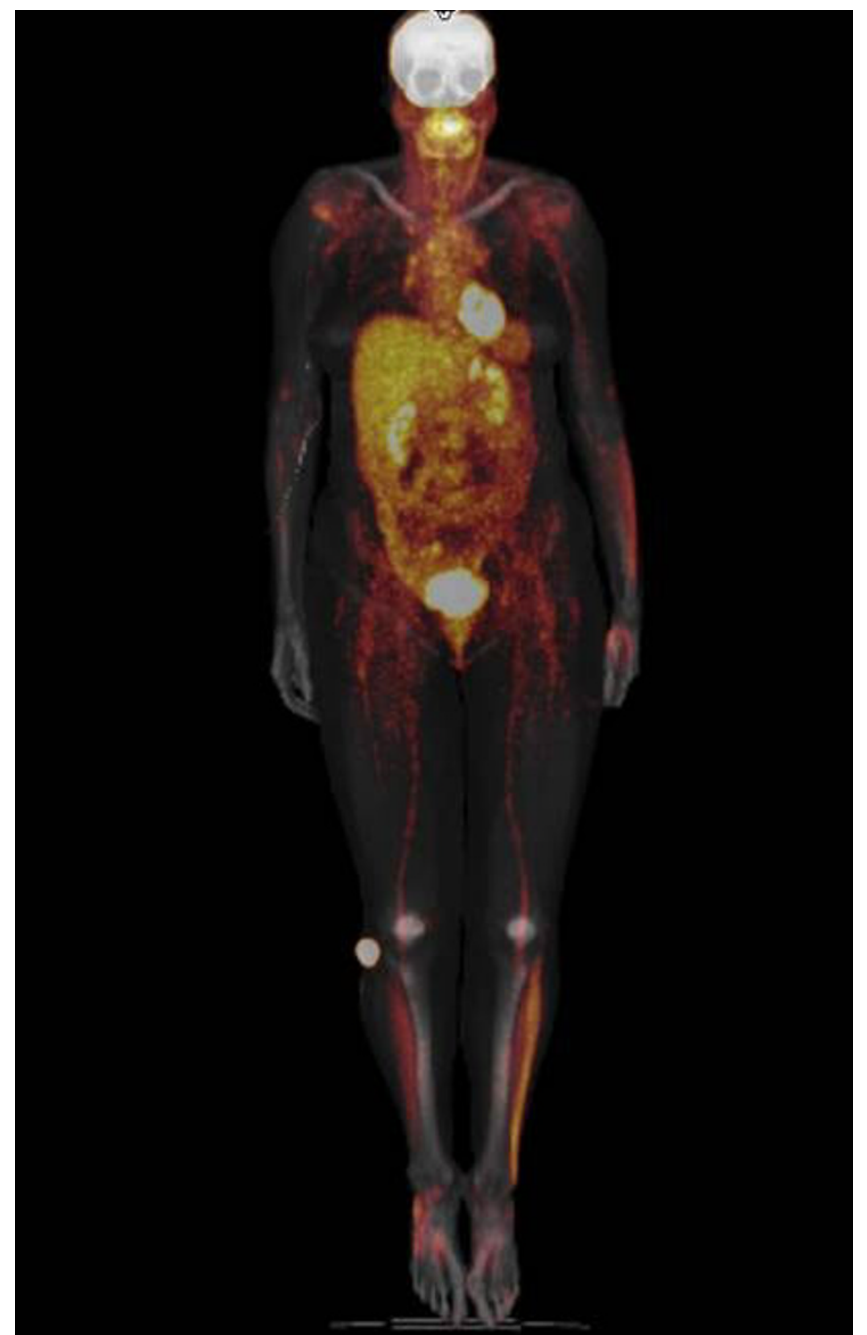

Figure 15

Metabolic imaging using whole body ${ }^{18}$ F-Fluorodeoxyglucose PET and CT. Note the metabolic activity on the lateral side of the left lower limb as well as on the right ankle. The area around the ankle corresponds to the Shen mai acupuncture point which has been evaluated in our study. Shank muscles are commonly more active in locomotion. The image was provided courteously by Dr David Townsend, University of Tennessee [165].

1.3.3 IL-6 regulates the Zn transporter Zip-14 [244]

pro-inflammatory cytokines

1.3.4 Influence of aging [245]

1.3.5 granulocytes and neutrophils [106,246]

1.3.6 c-Fos and lipocortin II [215]

1.3.7 induction of histidine decarboxylase $[118,119]$

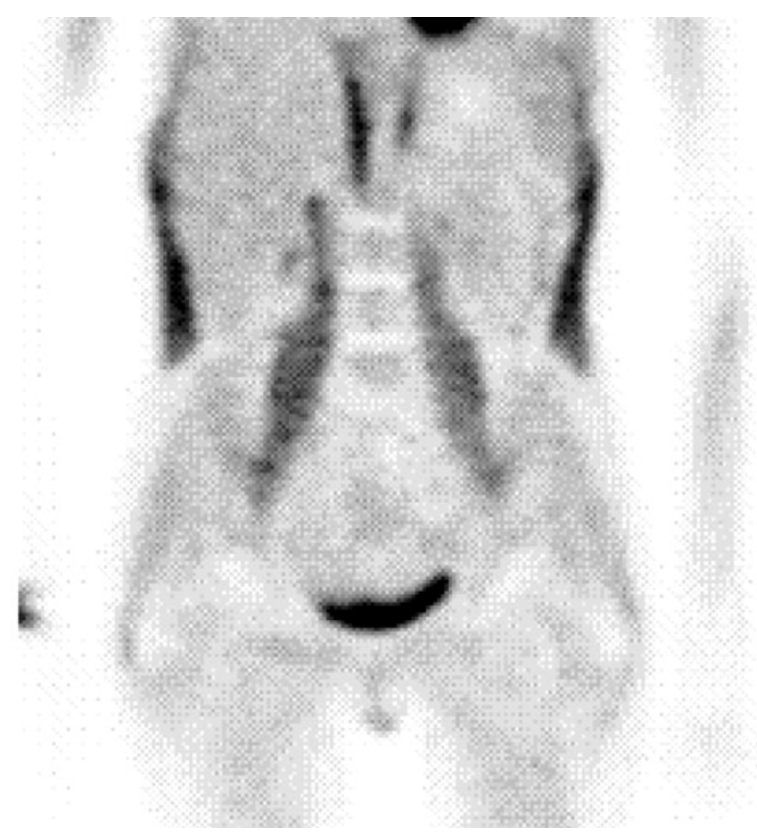

\section{Figure 16}

Metabolic imaging using ${ }^{18} \mathrm{~F}-\mathrm{Fluorodeoxyglucose} \mathrm{(I8F-FDG)}$ showing metabolic activity in the lateral abdomen (dark areas). These areas are located around the Dai mai point which has been evaluated in our study. The accompanying CT images shows a clear deviation of the body axis at the level of the trunk. The images are reproduced with kind permission of the Society of Nuclear Medicine [166].

1.3.8 increased levels of bradykinin [116]

1.3.9 interactions in nociception [247]

1.3.10 ubiquitin proteosome proteolysis [246]

1.3.11 role of gender [248]

1.3.12 Antioxidants diminish cytokine response [249]

1.3.13 activation of the c-Jun $\mathrm{NH}(2)$-terminal kinase (JNK) [250]

1.4 Elements of Ca regulation [251,252] and EC coupling [253]

1.4.1 reduced Ca levels [253,254]

1.4.2 ryanodine receptor, calmodulin [251,255]

1.4 .3 calsequestrin $[42,133,253]$

1.4.4 parvalbumin (in motoneuron) [137]

excitoxicity [256] 


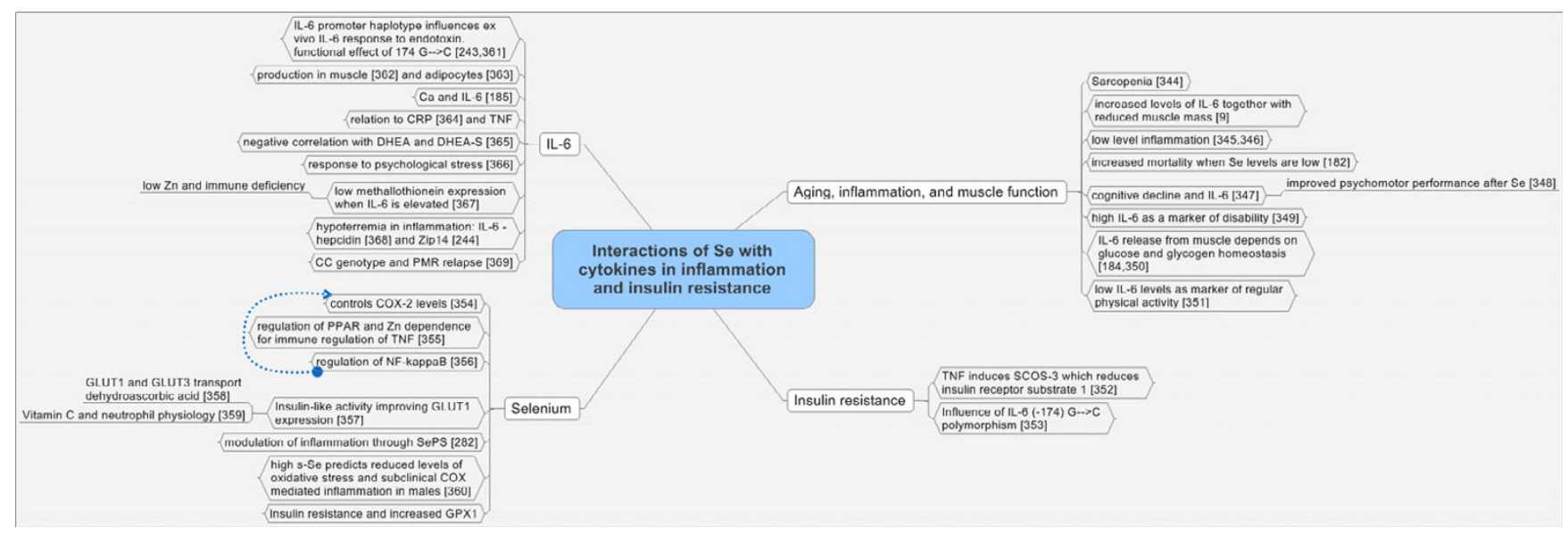

\section{Figure 17}

Graphical summary of scientific data related to inflammation as it can be applied in TAO and in metabolic disorders including insulin resistance. Interactions with IL-6 and Se are depicted.

\subsubsection{Ca, SERCA [254]}

SERCA 1 in fast twitch fibers [251]

SERCA 2 in slow twitch fibers [251]

SERCA in EOM [257]

Relation to thyroid hormones $[258,259]$

Relation to extraocular muscles [257]

\subsubsection{Triadin [253]}

1.4.7 Junctin in myocyte [218]

1.5 Muscle repair processes

1.5.1 mTOR $[260,261]$

1.5.2 Satellite cells [262-264]

1.5.3 Zn, MMP and remodelling [265,266]

1.5.4 Telomerase in fatigue associated myopathy [267]

2 Connective tissue [236]

2.1 mechanosensory effects $[268,269]$

2.2 mechanosensation of the skin [270]

2.3 Structural changes

\subsubsection{SOD changes? [271]}

2.3.2 release of glycosaminoglycans ? [27]

2.3.3 GAGs in ER [26]

2.3.4 Scarred fascia and GAGs [25]

2.4 interactions with collagen

2.4.1 collagen degrading enzymes: TIMP-1, TIMP2MMP2, MMP-9 [110,265,272,273]

2.4.2 procollagen processing [111]

2.5 Potential interaction with fasciae [240]

2.6 increased levels of bradykinin and adenosine $[115,116]$

3 Neuromuscular dysfunction [120,122,124,125]

\subsection{Reduced reflex sensitivity [121]}

3.2 Alpha motoneuron pool recruitment [122]

3.3 Alteration in sense of effort and motor command [123]

3.4 C-FOS expression in anterior pretectal nucleus in relation to pain [274]

3.5 C-FOS in the dorsal horn due to compression [275]

3.6 sensory control and inflammatory mediators [247] 
THE WOMED CONCEPT OF LATERAL TENSION low grade inflamation of the connective tissue in relation to an eccentric muscle function

1. Daily stressors of muscle function

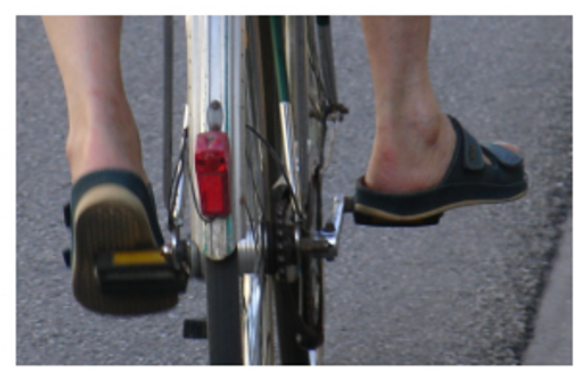

The right foot is externally rotated

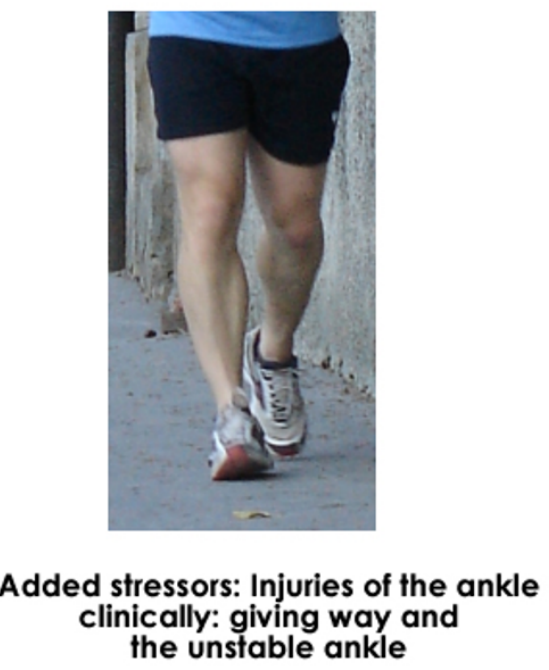

2. Eccentric muscle stretch

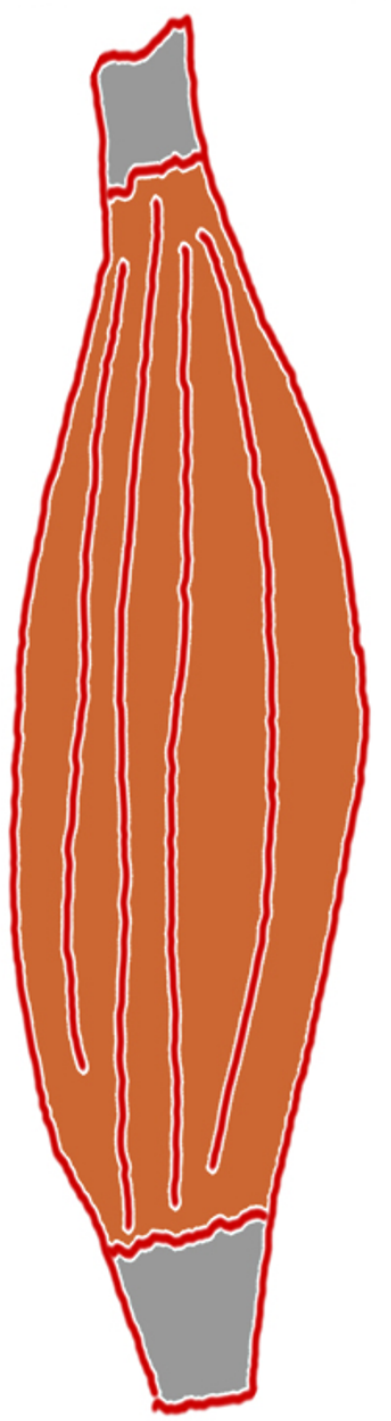

3. The cellular consequences of eccentric muscle stretch

Sarcomere disruption and inflammation

\section{Connective tissue damage}

Alteration in EC coupling and $\mathrm{Ca}++$

Mechanosensory effects

\section{Alteration of neuromuscular function}

Moving toes phenomenon signalizing lack of inhibition

Perpetuation through low levels of Se and Zn

Basic examination:

1. evaluate posture and gait

2. evaluate head position

3. identify altered propioception to stretch stimulus

4. erythrocyte levels of minerals and selenium

\section{Figure 18}

Abbridged representation of the WOMED concept of lateral tension in relation to inflammation and daily low level stressors. Further details can be extracted from figures 13, 14 and 17.

3.7 Neuromuscular activity modulates myonuclear domain size [263]

\subsection{Nervous system strategies [276]}

\subsubsection{Eccentric exercise and brain activation}

3.8.2 Brain activation and ECC

\subsubsection{Brain control of coordinated movements}

4 Nutritional and endocrine factors

\section{1 $\mathrm{Mg}$ and $\mathrm{Ca}$}

4.1.1 Decrease of the ion dependent binding of spin labeled ATP [277] 


\subsection{Selenium [55]}

4.2.1 Decreased levels in thyroid disease (Moncayo 2006)

4.2.2 Se in the pituitary [278]

4.2.3 Se and muscle [279]

4.2.4 Se and heart [280]

4.2.5 Se, mTOR and muscle hypertrophy [281]

4.3 Selenoproteins

4.3.1 Selenoprotein $\mathrm{S}$ influences inflammatory response [282]

4.3.2 Selenoprotein K - a cardiac antioxidant [280]

4.3.3 Selenoprotein N - muscular dystrophies [283]

4.3.4 Selenoprotein N1 - insulin resistance [284]

4.3.5 Selenoprotein W and muscle growth [285]

4.4 Zinc

4.4.1 Calsequestrin [133]

4.4.2 Bradykinin [286]

4.4.3 $\mathrm{Zn}$ and $\mathrm{Cu}$ and $\mathrm{Ca}$ binding proteins [287]

4.4.4 Influence on TRH processing [288]

4.4.5 $\mathrm{Zn}$ and MMP in muscle repair [265]

4.4.6 Zn and mTOR [289]

4.4.7 Synaptic activity [290]

4.4.8 Inhibitory activity in the spinal cord [146]

4.4.9 Sciatic nerve lesions and Zn transport [291]

4.5 Se and $Z n$

4.5.1 Zn-Se nanocrystals in the pituitary [292]

4.6 Vitamin E [293]

4.7 Thyroid hormones [294,295]

4.7.1 Regulation of muscle gene expression [294]
4.7.2 SERCA $[259,296]$

4.7.3 SERCA and thermogenesis [258]

4.7.4 Satellite cells [297]

4.7.5 Change in Myosin and SERCA isoforms [295]

4.7.6 Force reduction [298]

4.7.7 Changes in Ca uptake [299]

4.8 Insulin resistance $[300,301]$

4.9 Altered glycogen accumulation [302]

5 Muscle action of extraocular muscles

5.1 Consideration of muscle volume

5.1.1 EOM $[100,101]$

5.1.2 Volume of limb and abdominal muscles $[102,103]$

5.2 Inapparent $\mathrm{TAO}[303,304]$

5.3 Thyroid hormone receptors in EOM [305,306]

5.4 Satellite cells $[307,308]$

5.4.1 Activated satellite cells in overacting EOM [309]

5.5 Alterations in gaze [310]

5.6 SERCA in extraocular muscles[257]

5.7 Muscle overaction and Ca uptake [127]

5.8 Neck vibration in strabismus [311] associated with changes in congruent muscle propioceptive information

5.9 Head and eye movement in MRI [312]

5.10 Influence of waist disturbance on gait [313]

5.11 Ocular motility [314]

5.12 Layer specific EOM structure [128,315-317]

6 Role of brain integration in movement coordination

6.1 Interlimb coordination [318]

6.2 Lateralization of lower limb movements [151] 
6.3 Coordination of ankle movements [150]

6.4 Active and passive ankle movements [319]

Regulation of Ca Release [320]

1. Ca cycling [254]

2. SERCA

2.1. SERCA 1 fast fibers

2.1.1. Sarcolipin (SLN) [321,322]

2.1.2. Brody disease [320]

2.2. SERCA 2 slow fibers

2.2.1. Phospholamban (PLB) $[321,322]$

3. Calsequestrin (high capacity - low affinity)

3.1. CSQ1 fast

3.2. CSQ2 slow

3.2.1. CSQ2 deletion > catecholaminergic tachycardia [323]

\section{3. $\beta$ Dystroglygan and CSQ assembly}

4. Calreticulin [263]

4.1. cardiac myofibrillogenesis[324]

5. Na Ca exchanger [325]

6. IP3 $[43,326]$

6.1. Involvement in redox echange regulation [326]

7. Dihydropyridine receptor DHPR [251]

7.1. Voltage sensor

7.2. Linked to CSQ via junctional protein 45 [327]

7.3. Subtype 1

7.3.1. Malignant Hyperthermia

8. Ryanodine 3 gene products and splicing variants

8.1. RYR1 skeletal
8.1.1. minicore ophthalmoplegia

8.1.2. multi minicore disease

8.1.3. central core disease

8.1.4. malignant hyperthermia

8.2. $R y R 2$ cardiac

8.2.1. arrhythmias

8.3. RyR3 cephalic muscles

8.4. Regulation by thiols [328]

8.5. Importance of glutathione [329]

8.6. Importance of Se [330]

8.7. Junctin in the structure [331]

9. Ca buffers

9.1. Parvalbumin [41]

9.2. Troponin $C$

9.3. Calmodulin [332]

9.4. Histidin-rich calcium binding protein

9.5. Junctate

9.6. Sarcolumenin

9.7. Mitochondria

9.8. $S 100[333]$

10. Role of thyroid hormones [334]

10.1. Hyperthyroidisim

10.1.1. Upregulates $\mathrm{Na} \mathrm{Ca}$ exchanger

10.1.2. IP3

10.1.3. RyR

10.1.4. Myosin heavy chains

10.1.5. Gender specific action via $\beta E R B$

10.1.6. Low levels of $\mathrm{Zn}$ [79] 


\section{Role of Selenium and selenoproteins [279]}

11.1. Regulates functional thiols of $R y R$

11.1.1. oxidation $>$ open

11.1.2. reduction $>$ closed

11.2. Selenoprotein N [335]

11.2.1. Related to rigid spine [283]

11.2.2. Minicore ophthalmoplegia [336]

11.3. Selenoprotein $K$

11.3.1. Cardiac antioxidant [280]

11.4. Selenoprotein $W[337,338]$

11.4.1. Oxidative stress [285]

\section{Role of $\mathrm{Zn}$}

12.1. Modulation of activation and inactivation of $C a$ on $R y R$ [339]

12.2. Associated with T-tubules [340]

12.3. CSQ structure $[133,135]$

12.4. Ca Zn binding to calmodulin

12.5. $\mathrm{Ca} \mathrm{Zn}$ and MMP [341]

12.6. HRP regulation [135]

12.7. Higher levels in red muscle [342,343]

Interactions of Se with cytokines in inflammation and insulin resistance

\section{Aging, inflammation, and muscle function}

\subsection{Sarcopenia [344]}

1.2. increased levels of IL-6 together with reduced muscle mass [9]

\section{3. low level inflammation $[345,346]$}

1.4. increased mortality when Se levels are low [182]

1.5. cognitive decline and IL-6 [347]
1.5.1. improved psychomotor performance after Se [348]

1.6. high IL-6 as a marker of disability [349]

1.7. IL-6 release from muscle depends on glucose and glycogen homeostasis [184,350]

1.8. low IL-6 levels as marker of regular physical activity [351]

\section{Insulin resistance}

2.1. TNF induces SCOS-3 which reduces insulin receptor substrate 1 [352]

2.2. Influence of IL-6 (-174) G->C polymorphism [353]

\section{Selenium}

3.1. controls COX-2 levels [354]

3.2. regulation of PPAR and $\mathrm{Zn}$ dependence for immune regulation of TNF [355]

3.3. regulation of NF-kappaB [356]

Siehe auch: controls COX-2 levels

3.4. Insulin-like activity improving GLUT1 expression [357]

3.4.1. GLUT1 and GLUT3 transport dehydroascorbic acid [358]

3.4.2. Vitamin C and neutrophil physiology [359]

3.5. modulation of inflammation through SePS [282]

3.6. high s-Se predicts reduced levels of oxidative stress and subclinical COX mediated inflammation in males [360]

3.7. Insulin resistance and increased GPX1

\section{IL-6}

4.1. IL-6 promoter haplotype influences ex vivo IL-6 response to endotoxin. functional effect of $174 \mathrm{G}->C$ [243,361]

4.2. production in muscle [362] and adipocytes [363]

4.3. Ca and IL-6 [185]

4.4. relation to CRP [364] and TNF

4.5. negative correlation with DHEA and DHEA-S [365]

4.6. response to psychological stress [366] 
4.7. low methallothionein expression when IL-6 is elevated [367]

\subsection{1. low $\mathrm{Zn}$ and immune deficiency}

4.8. hypoferremia in inflammation: IL-6 - hepcidin [368] and Zip14 [244]

\subsection{CC genotype and PMR relapse [369]}

\section{Acknowledgements}

All patients provided written consent for participation and for their identities to be revealed in Figures 2 to 4. The whole-body PET CT image was kindly provided by SIEMENS (Erlangen, Germany). The European Journal of Nuclear Medicine and Molecular Imaging allowed us to reproduce the image shown in Figure 12. The Society of Nuclear Medicine allowed us to reproduce the image shown in Figure 16.

Financial funding was provided by WOMED.

\section{References}

I. Wall JR, Henderson J, Strakosch CR, Joyner DM: Graves' ophthalmopathy. Can Med Assoc J 198I, I 24:855-866.

2. Garrity JA, Bahn RS: Pathogenesis of graves ophthalmopathy: implications for prediction, prevention, and treatment. Am J Ophthalmol 2006, I 42: |47-I53.

3. Kiljanski J, Nebes V, Stachura I, Kennerdell JS, Wall JR: Should Graves' disease be considered a collagen disorder of the thyroid, skeletal muscle and connective tissue? Horm Metab Res 1995, 27:528-532.

4. Rapoport B, Alsabeh R, Aftergood D, McLachlan SM: Elephantiasic pretibial myxedema: insight into and a hypothesis regarding the pathogenesis of the extrathyroidal manifestations of Graves' disease. Thyroid 2000, 10:685-692.

5. Wall JR: Graves' disease is a multi-system autoimmune disorder in which extra ocular muscle damage and connective tissue inflammation are variable features. Thyroid 2002, I 2:35-36.

6. Yudkin JJ, Juhan-Vague I, Hawe E, Humphries SS, Di Minno G, Margaglione M, Tremoli E, Kooistra T, Morange PP, Lundman P, MohamedAli $V$, Hamsten A: Low-grade inflammation may play a role in the etiology of the metabolic syndrome in patients with coronary heart disease: The HIFMECH study. Metabolism 2004, 53:852-857.

7. Ritchie SA, Connell JM: The link between abdominal obesity, metabolic syndrome and cardiovascular disease. Nutr Metab Cardiovasc Dis 2006, .:

8. Das UN: Is metabolic syndrome $\mathbf{X}$ an inflammatory condition? Exp Biol Med (Maywood) 2002, 227:989-997.

9. Visser M, Pahor M, Taaffe DR, Goodpaster BH, Simonsick EM, Newman $A B$, Nevitt M, Harris TB: Relationship of interleukin-6 and tumor necrosis factor-alpha with muscle mass and muscle strength in elderly men and women: the Health ABC Study. J Gerontol A Biol Sci Med Sci 2002, 57:M326-M332.

10. Salvi M, Girasole G, Pedrazzoni M, Passeri M, Giuliani N, Minelli R, Braverman LE, Roti $E$ : Increased serum concentrations of interleukin-6 (IL-6) and soluble IL-6 receptor in patients with Graves' disease. J Clin Endocrinol Metab 1996, 81:2976-2979.

II. Molnar I, Balazs C: High circulating IL-6 level in Graves' ophthalmopathy. Autoimmunity 1997, 25:91-96.

12. Diez JJ, Hernanz A, Medina S, Bayon C, Iglesias P: Serum concentrations of tumour necrosis factor-alpha (TNF-alpha) and soluble TNF-alpha receptor p55 in patients with hypothyroidism and hyperthyroidism before and after normalization of thyroid function. Clin Endocrinol (Oxf) 2002, 57:5I5-52I.

13. Moncayo R, Herold M, Riccabona G: Serum levels of interleukin 6 (IL-6) are elevated in patients with active thyroid associated ophthalmopathy (TAO). J Endocrinol Invest 1997, 5 Suppl.:20.

14. Salvi M, Pedrazzoni M, Girasole G, Giuliani N, Minelli R, Wall JR, Roti $E$ : Serum concentrations of proinflammatory cytokines in
Graves' disease: effect of treatment, thyroid function, ophthalmopathy and cigarette smoking. Eur J Endocrinol 2000, 143:197-202.

15. Steensberg A, Keller C, Starkie RL, Osada T, Febbraio MA, Pedersen BK: IL-6 and TNF-alpha expression in, and release from, contracting human skeletal muscle. Am J Physiol Endocrinol Metab 2002, 283:EI 272-EI 278.

16. Brennan MD, Powell C, Kaufman KR, Sun PC, Bahn RS, Nair KS: The impact of overt and subclinical hyperthyroidism on skeletal muscle. Thyroid 2006, 16:375-380.

17. Cakir M, Samanci N, Balci N, Balci MK: Musculoskeletal manifestations in patients with thyroid disease. Clin Endocrinol (Oxf) 2003, 59:162-167.

18. Duyff RF, Van den BJ, Laman DM, van Loon BJ, Linssen WH: Neuromuscular findings in thyroid dysfunction: a prospective clinical and electrodiagnostic study. J Neurol Neurosurg Psychiatry 2000, 68:750-755.

19. Kiljanski Jl, Nebes V, Wall JR: The ocular muscle cell is a target of the immune system in endocrine ophthalmopathy. Int Arch Allergy Immunol 1995, 106:204-2 I2.

20. Kahaly G, Forster G, Hansen C: Glycosaminoglycans in thyroid eye disease. Thyroid 1998, 8:429-432.

21. Taylor KR, Gallo RL: Glycosaminoglycans and their proteoglycans: host-associated molecular patterns for initiation and modulation of inflammation. FASEBJ 2006, 20:9-22.

22. Hansen C, Otto E, Kuhlemann K, Forster G, Kahaly GJ: Glycosaminoglycans in autoimmunity. Clin exp Rheumatol 1996, 14 Suppl 15:S59-S67.

23. Kahaly G, Schuler M, Sewell AC, Bernhard G, Beyer J, Krause U: Urinary glycosaminoglycans in Graves' ophthalmopathy. Clin Endocrinol (Oxf) 1990, 33:35-44.

24. Bahn RS: Clinical review I57: Pathophysiology of Graves' ophthalmopathy: the cycle of disease. J Clin Endocrinol Metab 2003, 88:1939-1946.

25. Kozma EM, Olczyk K, Glowacki A, Bobinski R: An accumulation of proteoglycans in scarred fascia. Mol Cell Biochem 2000, 203:103-112

26. Majors AK, Austin RC, De La Motte CA, Pyeritz RE, Hascall VC, Kessler SP, Sen G, Strong SA: Endoplasmic reticulum stress induces hyaluronan deposition and leukocyte adhesion. I Biol Chem 2003, 278:47223-4723।.

27. Karlsson K, Lindahl U, Marklund SL: Binding of human extracellular superoxide dismutase $C$ to sulphated glycosaminoglycans. Biochem J 1988, 256:29-33.

28. Hara $H$, Ban $Y$, Sato $R$ : [Serum superoxide dismutase in patients with Graves' disease]. Nippon Naibunpi Gakkai Zasshi 1993, 69:87-92

29. Moncayo R: Autoimmunity of endocrine ophthalmopathy. Immunological characterization of the circulating antibodies and biochemical properties of the isolated soluble eye muscle antigen. Acta Endocrinol (Copenh) 1989, I I I Suppl.2:99-106.

30. Zhang ZG, Wall JR, Bernard NF: Tissue distribution and quantitation of a gene expressing a 64- kDa antigen associated with thyroid-associated ophthalmopathy. Clin Immunol Immunopathol 1996, 80:236-244.

31. Sakata S, Fuwa Y, Goshima E, Nakamura S, Yamakita N, Maeda M, Miura K: A case of Graves' disease associated with polymyositis. J Endocrinol Invest 1989, I 2:837-840.

32. Appel SH, Stockton-Appel V, Stewart SS, Kerman RH: Amyotrophic lateral sclerosis. Associated clinical disorders and immunological evaluations. Arch Neurol 1986, 43:234-238.

33. Mase G, Ros S, Gemma A, Bonfigli L, Carraro N, Cazzato G, Rolfo M, Zanconati F, Sepcic J, Jurjevic A, Pirulli D, Boniotto M, Zezlina S, Crovella $S$, Amoroso $A$ : ALS with variable phenotypes in a six-generation family caused by leul44phe mutation in the SODI gene. J Neurol Sci 200 I, I 9 I: I I-18.

34. Caparros-Lefebvre D, Benabdallah S, Bertagna X, Ekindi N: [Subacute motor neuropathy induced by $\mathrm{T} 3$ hyperthyroidism]. Ann Med Interne (Paris) 2003, 1 54:475-478.

35. Harati $Y$, Patten BM: Prednisone use in concurrent autoimmune diseases. Arch Neurol 1979, 36:103-106.

36. Mihori A, Morio T, Nakayama M, Ono S, Shimizu N: [A case of fasciitis associated with Basedow's disease and polymyositis]. Rinsho Shinkeigaku 1998, 38:27-31. 
37. Smiley AM, Husain M, Indenbaum S: Eosinophilic fasciitis in association with thyroid disease: a report of three cases. I Rheumatol 1980, 7:87|-876.

38. Delporte MP, Benayoun R, Willer JC, Thomas M: [Muscular and nervous system manifestations of Graves' disease]. Sem Hop 1977, 53:1835-1842.

39. Kammer GM, Hamilton CR Jr.: Acute bulbar muscle dysfunction and hyperthyroidism. A study of four cases and review of the literature. Am J Med 1974, 56:464-470.

40. Gopinath B, Musselman R, Beard N, El Kaissi S, Tani J, Adams CL Wall JR: Antibodies targeting the calcium binding skeleta muscle protein calsequestrin are specific markers of ophthalmopathy and sensitive indicators of ocular myopathy in patients with Graves' disease. Clin Exp Immunol 2006, I 45:56-62.

4I. Berchtold MW, Brinkmeier $\mathrm{H}$, Muntener M: Calcium ion in skeletal muscle: its crucial role for muscle function, plasticity, and disease. Physiol Rev 2000, 80: I2I5-1265.

42. Beard NA, Laver DR, Dulhunty AF: Calsequestrin and the calcium release channel of skeletal and cardiac muscle. Prog Biophys Mol Biol 2004, 85:33-69.

43. Rossi AE, Dirksen RT: Sarcoplasmic reticulum: the dynamic calcium governor of muscle. Muscle Nerve 2006, 33:7I5-73I.

44. De Bellis A, Sansone D, Coronella C, Conte M, lorio S, Perrino S, Battaglia M, Bellastella G, Wall JR, Bellastella A, Bizzarro A: Serum antibodies to collagen XIII: a further good marker of active Graves' ophthalmopathy. Clin Endocrinol (Oxf) 2005, 62:24-29.

45. Hägg $P$, Väisänen $T$, Tuomisto $A$, Rehn $M, T u$ H, Huhtala $P$, Eskelinen S, Pihlajaniemi T: Type XIII collagen: a novel cell adhesion component present in a range of cell-matrix adhesions and in the intercalated discs between cardiac muscle cells. Matrix Biol 200I, I 9:727-742

46. Chen YK, Chen YL, Liao AC, Shen YY, Kao CH: Elevated I8F-FDG uptake in skeletal muscles and thymus: a clue for the diagnosis of Graves' disease. Nucl Med Commun 2004, 25: I I 5- I 2 I.

47. Wenger M, Gasser R, Donnemiller E, Erler H, Glossmann H, Patsch JR, Moncayo R, Schirmer M: Images in cardiovascular medicine. Generalized large vessel arteritis visualized by I 8fluorodeoxyglucose-positron emission tomography. Circulation 2003, 107:923.

48. Bombardieri E, Aktolun C, Baum RP, Bishof-Delaloye A, Buscombe J, Chatal JF, Maffioli L, Moncayo R, Mortelmans L, Reske SN: FDG PET: procedure guidelines for tumour imaging. Eur J Nucl Med Mol Imaging 2003, 30:BPI I5-BPI 24

49. Moncayo R: Cubilin and megalin in radiation-induced renal injury with labelled somatostatin analogues: are we just dealing with the kidney? Eur J Nucl Med Mol Imaging 2005, 32: I|31-I|35

50. Kainz H, Bale R, Donnemiller E, Gabriel M, Kovacs P, Decristoforo $C$ Moncayo R: Image fusion analysis of $(99 \mathrm{~m}) \mathrm{Tc}-\mathrm{HYNIC-octre-}$ otide scintigraphy and CT/MRI in patients with thyroid-associated orbitopathy: the importance of the lacrimal gland. Eur J Nucl Med Mol Imaging 2003, 30: I I55-I I 59.

5I. Gibson IJ: Visually controlled locomotion and visual orientation in animals. BrJ Psychol 1958, 49:182-194.

52. Mergner T, Schweigart G, Botti F, Lehmann A: Eye movements evoked by proprioceptive stimulation along the body axis in humans. Exp Brain Res 1998, I 20:450-460.

53. Freedman KB, Bernstein J: Educational deficiencies in musculoskeletal medicine. I Bone Joint Surg Am 2002, 84-A:604-608.

54. Erkan D, Paget SA: The musculoskeletal roads less traveled. Curr Opin Rheumatol 2005, 1 7:62-63.

55. Roll JP, Vedel JP, Roll R: Eye, head and skeletal muscle spindle feedback in the elaboration of body references. Prog Brain Res 1989, 80:113-123.

56. Van Buskirk RL: Nociceptive reflexes and the somatic dysfunction: a model. J Am Osteopath Assoc 1990, 90:792-809.

57. Lynch SM, Boswell SA, Colon W: Kinetic stability of Cu/Zn superoxide dismutase is dependent on its metal ligands: implications for ALS. Biochemistry 2004, 43: |6525- |653|

58. Lynch SM, Colon W: Dominant role of copper in the kinetic stability of $\mathrm{Cu} / \mathrm{Zn}$ superoxide dismutase. Biochem Biophys Res Commun 2006, 340:457-46I

59. Saglam K, Serce AF, Yilmaz MI, Bulucu F, Aydin A, Akay C, Sayal A: Trace elements and antioxidant enzymes in Behcet's disease. Rheumatol Int 2002, 22:93-96.
60. Werner SC: Modification of the classification of the eye changes of Graves' disease: recommendation of the ad hoc committee of the American Thyroid Association. J Clin Endocrinol Metab 1977, 44:203-204.

61. Ferrario VF, Sforza C, Colombo A, Schmitz JH, Serrao G: Morphometry of the orbital region: a soft-tissue study from adolescence to mid-adulthood. Plast Reconstr Surg 200I, I 08:285-292.

62. Schmid M, De Nunzio AM, Schieppati M: Trunk muscle proprioceptive input assists steering of locomotion. Neurosci Lett 2005 , 384: $|27-| 32$.

63. Lambertz D, Goubel F, Kaspranski R, Perot C: Influence of longterm spaceflight on neuromechanical properties of muscles in humans. J Appl Physiol 2003, 94:490-498.

64. Collins DF, Refshauge KM, Todd G, Gandevia SC: Cutaneous receptors contribute to kinesthesia at the index finger, elbow, and knee. J Neurophysiol 2005, 94: I699-I706.

65. Burtscher E, Eppler-Tschiedel M, Gerz W, Suntinger A: AK Meridiantherapie (AKMT) Ist. edition. München, AKSE; 2003.

66. Garten H: Applied Kinesiology als funktionelle Neurologie. Manuelle Medizin 2000, 38: I20-I64.

67. Moncayo R, Moncayo $\mathrm{H}$, Ulmer $\mathrm{H}$, Kainz $\mathrm{H}$ : New diagnostic and therapeutic approach to thyroid associated orbitopathy based on Applied Kinesiology and homeopathic therapy. J Altern Complement Med 2004, 1 0:643-650.

68. Perot C, Meldener R, Goubel F: Objective measurement of proprioceptive technique consequences on muscular maximal voluntary contraction during manual muscle testing. Agressologie 1991, 32:47|-474.

69. Spillane JD, Nathan PW, Kelly RE, Marsden CD: Painful legs and moving toes. Brain 1971, 94:54I-556.

70. Schott GD: "Painful legs and moving toes": the role of trauma. J Neurol Neurosurg Psychiatry 198I, 44:344-346.

7I. Walters AS, Hening WA, Shah SK, Chokroverty S: Painless legs and moving toes: a syndrome related to painful legs and moving toes? Mov Disord 1993, 8:377-379.

72. Dressler D, Thompson PD, Gledhill RF, Marsden CD: The syndrome of painful legs and moving toes. Mov Disord 1994, 9:|3-2|

73. Ebersbach G, Schelosky L, Schenkel A, Scholz U, Poewe W: Unilateral painful legs and moving toes syndrome with moving fingers--evidence for distinct oscillators. Mov Disord 1998, I 3:965-968.

74. Baker JT, Donoghue JP, Sanes JN: Gaze direction modulates finger movement activation patterns in human cerebral cortex. I Neurosci 1999, 19:10044-10052.

75. Ehrsson HH, Naito E, Geyer S, Amunts K, Zilles K, Forssberg H, Roland PE: Simultaneous movements of upper and lower limbs are coordinated by motor representations that are shared by both limbs: a PET study. Eur J Neurosci 2000, I 2:3385-3398.

76. Milias GA, Nomikos T, Fragopoulou E, Athanasopoulos S, Antonopoulou S: Effects of baseline serum levels of Se on markers of eccentric exercise-induced muscle injury. Biofactors 2006 , 26: $16|-| 70$

77. Milias GA, Nomikos T, Fragopoulou E, Athanasopoulos S, Antonopoulou S: Effects of eccentric exercise-induced muscle injury on blood levels of platelet activating factor (PAF) and other inflammatory markers. Eur J Appl Physiol 2005, 95:504-5 I 3.

78. Swaminathan R, Segall NH, Chapman C, Morgan DB: Red-blood-cell composition in thyroid disease. Lancet 1976, 2:1382-1385.

79. Nishi $\mathrm{Y}, \mathrm{Kawate} \mathrm{R}$, Usui T: Zinc metabolism in thyroid disease. Postgrad Med J 1980, 56:833-837.

80. Bettger WJ: Zinc and selenium, site-specific versus general antioxidation. Can I Physiol Pharmacol 1993, 71:721-724.

8I. Hellwig D, Ukena D, Paulsen F, Bamberg M, Kirsch CM: Metaanalyse zum Stellenwert der Positronen-Emissions-Tomographie mit F-I8-Fluorodesoxyglukose (FDG-PET) bei Lungentumoren. Pneumologie 200I, 55:367-377.

82. Blazsek I, Mathe G: Zinc and immunity. Biomed Pharmacother 1984 38:187-193.

83. Prasad AS, Meftah S, Abdallah J, Kaplan J, Brewer GJ, Bach JF, Dardenne M: Serum thymulin in human zinc deficiency. I Clin Invest 1988, 82:1202-1210.

84. Chandra RK: Nutrition and immunology: from the clinic to cellular biology and back again. Proc Nutr Soc 1999, 58:68|-683. 
85. Fraker PJ, King LE, Laakko T, Vollmer TL: The dynamic link between the integrity of the immune system and zinc status. J Nutr 2000, I30:1399S-1406S.

86. Otteson DC, Lai H, Liu Y, Zack DJ: Zinc-finger domains of the transcriptional repressor KLFI 5 bind multiple sites in rhodopsin and IRBP promoters including the CRS-I and G-rich repressor elements. BMC Mol Biol 2005, 6:I5.

87. Redenti S, Chappell RL: Neuroimaging of zinc released by depolarization of rat retinal cells. Vision Res 2005, 45:3520-3525.

88. Grahn BH, Paterson PG, Gottschall-Pass KT, Zhang Z: Zinc and the eye. J Am Coll Nutr 200I, 20:106-I I8.

89. Saraux $H$, Bechetoille A, Nou B, Courtois B: [The diminution of the level of serum zinc during some toxic optic neuritis cases]. Ann d'Oculistique 1975, 208:29-31.

90. Winsa B, Mandahl A, Karlsson FA: Graves' disease, endocrine ophthalmopathy and smoking. Acta Endocrinol (Copenh) 1993, I 28: 156-160.

91. Prummel MF, Wiersinga WM: Smoking and risk of Graves' disease. JAMA 1993, 269:479-482.

92. Uz E, Sahin S, Hepsen IF, Var A, Sogut S, Akyol O: The relationship between serum trace element changes and visual function in heavy smokers. Acta Ophthalmol Scand 2003, 81: I6I-164.

93. Isaacson A, Bianchi CP, Sandow A: Zinc 65 distribution and movement in frog skeletal muscle and tendon. Am J Physiol 1970, 2 1 8: 1239-1248.

94. Moncayo R, Moncayo M, Moncayo H: Entspannungstherapie mittels Akupressur und Augenbewegungen. Ergebniskontrolle durch Applied Kinesiology Methoden. Dt Ztschr f Akup 2006, 49:19-26.

95. Moncayo R, Baldissera I, Decristoforo C, Kendler D, Donnemiller E: Evaluation of immunological mechanisms mediating thyroid-associated ophthalmopathy by radionuclide imaging using the somatostatin analog I I I In-octreotide. Thyroid I997, 7:21-29.

96. Bove M, Diverio M, Pozzo T, Schieppati M: Neck muscle vibration disrupts steering of locomotion. J Appl Physiol 200 I, 9 I:58I-588.

97. Schieppati M, Nardone A, Schmid M: Neck muscle fatigue affects postural control in man. Neuroscience 2003, I 2 I :277-285.

98. Schmid M, Schieppati M: Neck muscle fatigue and spatial orientation during stepping in place in humans. J Appl Physiol 2005 99: $141-153$

99. Stapley PJ, Beretta MV, Dalla TE, Schieppati M: Neck muscle fatigue and postural control in patients with whiplash injury. Clin Neurophysiol 2006, I I 7:610-622.

100. Kvetny J, Puhakka KB, Rohl L: Magnetic resonance imaging determination of extraocular eye muscle volume in patients with thyroid-associated ophthalmopathy and proptosis. Acta Ophthalmol Scand 2006, 84:419-423.

I0I. Tian S, Nishida Y, Isberg B, Lennerstrand G: MRI measurements of normal extraocular muscles and other orbital structures. Graefes Arch Clin Exp Ophthalmol 2000, 238:393-404

102. Müller MJ, Bosy-Westphal A, Kutzner D, Heller M: Metabolically active components of fat-free mass and resting energy expenditure in humans: recent lessons from imaging technologies. Obes Rev 2002, 3: I I3-122.

103. Lee S], Janssen I, Heymsfield SB, Ross R: Relation between wholebody and regional measures of human skeletal muscle. $A m \mathrm{~J}$ Clin Nutr 2004, 80:1215-1221.

104. Peake J, Nosaka K, Suzuki K: Characterization of inflammatory responses to eccentric exercise in humans. Exerc Immunol Rev 2005, I I:64-85.

105. Sesto ME, Radwin RG, Block WF, Best TM: Anatomical and mechanical changes following repetitive eccentric exertions. Clin Biomech (Bristol, Avon) 2005, 20:4l-49.

106. Maclntyre DL, Reid WD, Lyster DM, Szasz IJ, McKenzie DC: Presence of WBC, decreased strength, and delayed soreness in muscle after eccentric exercise. I Appl Physiol 1996 80:1006-1013

107. Lieber RL, Thornell LE, Fridén J: Muscle cytoskeletal disruption occurs within the first I 5 min of cyclic eccentric contraction. J Appl Physiol 1996, 80:278-284.

108. Maclntyre DL, Sorichter S, Mair J, Berg A, McKenzie DC: Markers of inflammation and myofibrillar proteins following eccentric exercise in humans. Eur J Appl Physiol 2001, 84: I80-186.
109. Lieber RL, Shah S, Fridén J: Cytoskeletal disruption after eccentric contraction-induced muscle injury. Clin Orthop Relat Res 2002, 403 Suppl.:S90-S99.

I 10. Koskinen SO, Höyhtyä M, Turpeenniemi-Hujanen T, Martikkala V Mäkinen TT, Oksa J, Rintamäki H, Löfberg M, Somer H, Takala TE: Serum concentrations of collagen degrading enzymes and their inhibitors after downhill running. Scand J Med Sci Sports 2001, I I:9-15.

III. Crameri RM, Langberg H, Teisner B, Magnusson P, Schrøder HD, Olesen JL, Jensen CH, Koskinen S, Suetta C, Kjaer M: Enhanced procollagen processing in skeletal muscle after a single bout of eccentric loading in humans. Matrix Biol 2004, 23:259-264.

I I2. Gregory JE, Morgan DL, Proske U: Tendon organs as monitors of muscle damage from eccentric contractions. Exp Brain Res 2003, I 5 I:346-355.

I I3. Itoh K, Kawakita K: Effect of indomethacin on the development of eccentric exercise-induced localized sensitive region in the fascia of the rabbit. Ipn J Physiol 2002, 52:I73-I80.

I14. Willoughby DS, Vanenk C, Taylor L: Effects of concentric and eccentric contractions on exercise-induced muscle injury, inflammation, and serum IL-6. I Exer Physiol Online 2003, 6:8-I 5.

II5. Blais C Jr., Adam A, Massicotte D, Peronnet F: Increase in blood bradykinin concentration after eccentric weight-training exercise in men. J Appl Physiol 1999, 87: I 197-I201.

1 16. Langberg H, Bjorn C, Boushel R, Hellsten Y, Kjaer M: Exerciseinduced increase in interstitial bradykinin and adenosine concentrations in skeletal muscle and peritendinous tissue in humans. J Physiol 2002, 542:977-983.

I 17. Tomiya A, Aizawa T, Nagatomi R, Sensui H, Kokubun S: Myofibers express IL-6 after eccentric exercise. Am J Sports Med 2004, 32:503-508

I I8. Endo Y, Tabata T, Kuroda H, Tadano T, Matsushima K, Watanabe M: Induction of histidine decarboxylase in skeletal muscle in mice by electrical stimulation, prolonged walking and interleukin-I. J Physiol 1998, 509:587-598.

I19. Ayada K, Watanabe M, Endo Y: Elevation of histidine decarboxylase activity in skeletal muscles and stomach in mice by stress and exercise. Am J Physiol Regul Integr Comp Physiol 2000, 279:R2042-R2047.

120. Saxton JM, Clarkson PM, James R, Miles M, Westerfer M, Clark S, Donnelly AE: Neuromuscular dysfunction following eccentric exercise. Med Sci Sports Exerc 1995, 27: I I85-II93.

12I. Avela J, Kyröläinen H, Komi PV, Rama D: Reduced reflex sensitivity persists several days after long-lasting stretch-shortening cycle exercise. I Appl Physiol 1999, 86: | 292-1300.

122. Kaufman T, Burke JR, Davis JM, Durstine JL: Exercise-induced neuromuscular dysfunction under reflex conditions. Eur J Appl Physiol 200I, 84:5I0-520.

123. Carson RG, Riek S, Shahbazpour N: Central and peripheral mediation of human force sensation following eccentric or concentric contractions. J Physiol 2002, 539:913-925.

124. Byrne C, Twist C, Eston R: Neuromuscular function after exercise-induced muscle damage: theoretical and applied implications. Sports Med 2004, 34:49-69.

125. Bottas R, Linnamo V, Nicol C, Komi PV: Repeated maximal eccentric actions causes long-lasting disturbances in movement control. Eur J Appl Physiol 2005, 94:62-69.

126. Genthon N, Rougier P: Influence of an asymmetrical body weight distribution on the control of undisturbed upright stance. J Biomech 2005, 38:2037-2049.

127. Kim HS, Chang YH, Kim H, Park SR, Han SH, Lee JB: Calcium uptake and release through sarcoplasmic reticulum in the inferior oblique muscles of patients with inferior oblique overaction. Yonsei Med J 2006, 47:207-2I 3.

128. Budak MT, Bogdanovich S, Wiesen MH, Lozynska O, Khurana TS, Rubinstein NA: Layer-specific differences of gene expression in extraocular muscles identified by laser-capture microscopy. Physiol Genomics 2004, 20:55-65.

129. Ragusa RJ, Chow CK, St Clair DK, Porter JD: Extraocular, limb and diaphragm muscle group-specific antioxidant enzyme activity patterns in control and mdx mice. J Neurol Sci 1996, I39:180-186.

130. Khurana TS, Prendergast RA, Alameddine H, Torne MS, Fardeau M, Arahata K, Sugita H, Kunkel LM: Absence of extraocular muscle pathology in Duchenne muscular dystrophy: role for calcium 
homeostasis in extraocular muscle sparing. J Exp Med 1995 1 82:467-475.

131. Moncayo R, Moncayo $\mathrm{H}$, Kapelari K: Nutritional treatment of incipient thyroid autoimmune disease. Influence of selenium supplementation on thyroid function and morphology in children and young adults. Clin Nutr 2005, 24:530-53I.

132. Turker O, Kumanlioglu K, Karapolat I, Dogan I: Selenium treatment in autoimmune thyroiditis: 9-month follow-up with variable doses. I Endocrinol 2006, I90:I5I-I56.

133. Baksh S, Spamer C, Oikawa K, McCubbin WD, Heilmann C, Kay CM, Michalak M: Zn2+ binding to cardiac calsequestrin. Biochem Biophys Res Commun 1995, 209:310-315

134. Takahashi N, Atsumi H, Nakada S, Takeishi Y, Tomoike H: Alterations in the inotropic responses to forskolin and $\mathrm{Ca}+$ and reduced gene expressions of $\mathrm{Ca2+-signaling} \mathrm{proteins}$ induced by chronic volume overload in rabbits. Jpn Circ J 2000, 64:86I-867.

135. Picello E, Damiani E, Margreth A: Low-affinity $\mathbf{C a ( 2 + ) - b i n d i n g ~}$ sites versus $\mathrm{Zn}(2+)$-binding sites in histidine-rich $\mathrm{Ca}(2+)$ binding protein of skeletal muscle sarcoplasmic reticulum. Biochem Biophys Res Commun 1992, I 86:659-667.

136. Kruman II, Pedersen WA, Springer JE, Mattson MP: ALS-linked Cu/ $\mathrm{Zn}$-SOD mutation increases vulnerability of motor neurons to excitotoxicity by a mechanism involving increased oxidative stress and perturbed calcium homeostasis. Exp Neurol 1999, 160:28-39.

137. Siklos L, Engelhardt Jl, Alexianu ME, Gurney ME, Siddique T, Appel SH: Intracellular calcium parallels motoneuron degeneration in SOD-I mutant mice. J Neuropathol Exp Neurol 1998, 57:57|-587.

138. Marklund SL, Holme E, Hellner L: Superoxide dismutase in extracellular fluids. Clin Chim Acta 1982, I 26:4I-5I.

139. Salvemini D, Muscoli C, Riley DP, Cuzzocrea S: Superoxide dismutase mimetics. Pulm Pharmacol Ther 2002, 15:439-447.

140. Zelko IN, Mariani TJ, Folz RJ: Superoxide dismutase multigene family: a comparison of the CuZn-SOD (SODI), Mn-SOD (SOD2), and EC-SOD (SOD3) gene structures, evolution, and expression. Free Radic Biol Med 2002, 33:337-349.

14I. Due AV, Petersen SV, Valnickova Z, Ostergaard L, Oury TD, Crapo JD, Enghild Jj: Extracellular superoxide dismutase exists as an octamer. FEBS Lett 2006, 580: | 485-|489.

142. Galland L: Biochemical abnormalities in patients with multiple chemical sensitivities. Occup Med 1987, 2:7I3-720.

143. Olin KL, Golub MS, Gershwin ME, Hendrickx AG, Lönnerdal B, Keen $C L$ : Extracellular superoxide dismutase activity is affected by dietary zinc intake in nonhuman primate and rodent models. Am J Clin Nutr 1995, 61:1263-1267.

144. Dastych M, Vlach O: Zinc status in patients with idiopathic scoliosis. Spine 1990, I 5:65-66.

145. Nagai M, Hasegawa M, Takehara K, Sato S: Novel autoantibody to $\mathrm{Cu} / \mathrm{Zn}$ superoxide dismutase in patients with localized scleroderma. J Invest Dermatol 2004, I 22:594-60I.

146. Danscher G, Jo SM, Varea E, Wang Z, Cole TB, Schrøder HD: Inhibitory zinc-enriched terminals in mouse spinal cord. Neuroscience 200I, 105:94I-947.

147. Jo SM, Danscher G, Daa SH, Won MH, Cole TB: Zinc-enriched (ZEN) terminals in mouse spinal cord: immunohistochemistry and autometallography. Brain Res 2000, 870:163-169.

148. Wang Z, Danscher G, Kim YK, Dahlstrom A, Mook JS: Inhibitory zinc-enriched terminals in the mouse cerebellum: doubleimmunohistochemistry for zinc transporter 3 and glutamate decarboxylase. Neurosci Lett 2002, 321:37-40.

149. Dai TH, Liu JZ, Sahgal V, Brown RW, Yue GH: Relationship between muscle output and functional MRI-measured brain activation. Exp Brain Res 200I, 140:290-300.

150. Ciccarelli O, Toosy AT, Marsden JF, Wheeler-Kingshott CM, Sahyoun C, Matthews PM, Miller DH, Thompson AJ: Identifying brain regions for integrative sensorimotor processing with ankle movements. Exp Brain Res 2005, 166:31-42.

15I. Kapreli E, Athanasopoulos S, Papathanasiou M, Van Hecke P, Strimpakos N, Gouliamos A, Peeters R, Sunaert S: Lateralization of brain activity during lower limb joints movement. An fMRI study. Neuroimage 2006, 32: I709-I72I.

152. de Jong A, Kilbreath SL, Refshauge KM, Adams R: Performance in different proprioceptive tests does not correlate in ankles with recurrent sprain. Arch Phys Med Rehabil 2005, 86:2 I0I-2I05.
153. Mora I, Quinteiro-Blondin S, Perot C: Electromechanical assessment of ankle stability. Eur J Appl Physiol 2003, 88:558-564.

154. Guralnik JM, Ferrucci L, Simonsick EM, Salive ME, Wallace RB: Lower-extremity function in persons over the age of 70 years as a predictor of subsequent disability. $N$ Engl J Med 1995, 332:556-56I.

155. Kavounoudias A, Roll R, Roll JP: The plantar sole is a 'dynamometric map' for human balance control. Neuroreport 1998, 9:3247-3252.

156. Kavounoudias A, Roll R, Roll JP: Foot sole and ankle muscle inputs contribute jointly to human erect posture regulation. J Physiol 200I, 532:869-878.

157. Becker RF: The meaning of fascia and fascial continuity. Osteopath Ann 1975, 3:8-32.

158. Hausdorff JM: Gait variability: methods, modeling and meaning. J Neuroengineering Rehabil 2005, 2: 19.

159. Mecagni C, Smith JP, Roberts KE, O'Sullivan SB: Balance and ankle range of motion in community-dwelling women aged 64 to 87 years: a correlational study. Phys Ther 2000, 80:1004-10II.

160. Siedentopf CM, Golaszewski SM, Mottaghy FM, Ruff CC, Felber S, Schlager A: Functional magnetic resonance imaging detects activation of the visual association cortex during laser acupuncture of the foot in humans. Neurosci Lett 2002, 327:53-56.

16I. Li G, Cheung RT, Ma QY, Yang ES: Visual cortical activations on fMRI upon stimulation of the vision-implicated acupoints. Neuroreport 2003, I 4:669-673.

162. Urquhart DM, Hodges PW, Story IH: Postural activity of the abdominal muscles varies between regions of these muscles and between body positions. Gait Posture 2005, 22:295-30I.

163. Urquhart DM, Hodges PW: Differential activity of regions of transversus abdominis during trunk rotation. Eur Spine J 2005, 14:393-400.

164. Urquhart DM, Barker PJ, Hodges PW, Story IH, Briggs CA: Regional morphology of the transversus abdominis and obliquus internus and externus abdominis muscles. Clin Biomech (Bristol, Avon) 2005, 20:233-24l.

165. Beyer T, Townsend DW: Putting 'clear' into nuclear medicine: a decade of PET/CT development. Eur J Nucl Med Mol Imaging 2006, 33:857-861.

166. Groves AM, Cheow HK, Win T, Balan KK: Extensive skeletal muscle uptake of I8F-FDG: relation to immunosuppressants? J Nucl Med Technol 2004, 32:206-208.

167. Drerup B, Hierholzer E: Automatic localization of anatomical landmarks on the back surface and construction of a bodyfixed coordinate system. J Biomech 1987, 20:961-970.

168. Fujimoto T, Itoh M, Kumano H, Tashiro M, Ido T: Whole-body metabolic map with positron emission tomography of a man after running. Lancet 1996, 348:266.

169. Tashiro M, Fujimoto T, Itoh M, Kubota K, Fujiwara T, Miyake M, Watanuki S, Horikawa E, Sasaki H, Ido T: I8F-FDG PET imaging of muscle activity in runners. I Nucl Med 1999, 40:70-76.

170. Fujimoto T, Itoh M, Tashiro M, Yamaguchi K, Kubota K, Ohmori H: Glucose uptake by individual skeletal muscles during running using whole-body positron emission tomography. Eur J Appl Physiol 2000, 83:297-302.

17I. Nuutila P, Kalliokoski K: Use of positron emission tomography in the assessment of skeletal muscle and tendon metabolism and perfusion. Scand J Med Sci Sports 2000, 10:346-350.

172. lemitsu M, Itoh M, Fujimoto T, Tashiro M, Nagatomi R, Ohmori H, Ishii $K$ : Whole-body energy mapping under physical exercise using positron emission tomography. Med Sci Sports Exerc 2000, 32:2067-2070.

173. Pappas GP, Olcott EW, Drace JE: Imaging of skeletal muscle function using (18)FDG PET: force production, activation, and metabolism. J Appl Physiol 200I, 90:329-337.

174. Fujimoto T, Kemppainen J, Kalliokoski KK, Nuutila P, Ito M, Knuuti J: Skeletal muscle glucose uptake response to exercise in trained and untrained men. Med Sci Sports Exerc 2003, 35:777-783.

175. Oi N, Iwaya T, Itoh M, Yamaguchi K, Tobimatsu Y, Fujimoto T: FDGPET imaging of lower extremity muscular activity during level walking. J Orthop Sci 2003, 8:55-6I.

176. Ohnuma M, Sugita T, Kokubun S, Yamaguchi K, Rikimaru H: Muscle activity during a dash shown by I8F-fluorodeoxyglucose positron emission tomography. J Orthop Sci 2006, I I:42-45. 
177. Bojsen-Møller J, Kalliokoski KK, Seppanen M, Kjaer M, Magnusson SP: Low-intensity tensile loading increases intratendinous glucose uptake in the Achilles tendon. I Appl Physiol 2006 , I0I:196-20I.

178. Hertel J: Functional instability following lateral ankle sprain. Sports Med 2000, 29:36I-37I.

179. Hintermann B: Biomechanics of the unstable ankle joint and clinical implications. Med Sci Sports Exerc I 999, 3 I :S459-S469.

180. Hubbard TJ, Kaminski TW, Vander Griend RA, Kovaleski JE: Quantitative assessment of mechanical laxity in the functionally unstable ankle. Med Sci Sports Exerc 2004, 36:760-766.

18I. Penha PJ, Joao SM, Casarotto RA, Amino C], Penteado DC: Postural assessment of girls between 7 and 10 years of age. Clinics 2005, 60:9-16.

182. Walston J, Xue Q, Semba RD, Ferrucci L, Cappola AR, Ricks M, Guralnik J, Fried LP: Serum antioxidants, inflammation, and total mortality in older women. Am J Epidemiol 2006, I 63:18-26.

183. Plomgaard P, Penkowa M, Pedersen BK: Fiber type specific expression of TNF-alpha, IL-6 and IL-I 8 in human skeletal muscles. Exerc Immunol Rev 2005, I I:53-63.

184. Pedersen BK, Steensberg A, Fischer C, Keller C, Keller P, Plomgaard $P$, Wolsk-Petersen E, Febbraio M: The metabolic role of IL-6 produced during exercise: is IL-6 an exercise factor? Proc Nutr Soc 2004, 63:263-267.

185. Juretic N, Garcia-Huidobro P, Iturrieta JA, Jaimovich E, Riveros N Depolarization-induced slow $\mathrm{Ca2}+$ transients stimulate transcription of IL-6 gene in skeletal muscle cells. Am J Physiol Cell Physiol 2006, 290:Cl428-CI436.

186. Rosendal L, Sogaard K, Kjaer M, Sjogaard G, Langberg H, Kristiansen $\mathrm{J}$ : Increase in interstitial interleukin-6 of human skeletal muscle with repetitive low-force exercise. J Appl Physiol 2005, 98:477-48I.

187. Shah JP, Phillips TM, Danoff JV, Gerber LH: An in vivo microanaIytical technique for measuring the local biochemical milieu of human skeletal muscle. J Appl Physiol 2005, 99: I977-1984.

188. Langberg H, Boushel R, Skovgaard D, Risum N, Kjaer M: Cyclo-oxygenase-2 mediated prostaglandin release regulates blood flow in connective tissue during mechanical loading in humans. J Physiol 2003, 55 I:683-689.

189. Levin O, Mizrahi J, Shoham M: Standing sway: iterative estimation of the kinematics and dynamics of the lower extremities from force-plate measurements. Biol Cybern 1998, 78:319-327.

190. Hodges PW, Richardson CA: Contraction of the abdominal muscles associated with movement of the lower limb. Phys Ther 1997, 77:132-142.

19I. Richardson CA, Snijders CJ, Hides JA, Damen L, Pas MS, Storm J: The relation between the transversus abdominis muscles, sacroiliac joint mechanics, and low back pain. Spine 2002 27:399-405.

192. Barker PJ, Guggenheimer KT, Grkovic I, Briggs CA, Jones DC, Thomas $C D$, Hodges PW: Effects of tensioning the lumbar fasciae on segmental stiffness during flexion and extension: Young Investigator Award winner. Spine 2006, 3 I:397-405.

193. Itoh K, Okada K, Kawakita K: A proposed experimental model of myofascial trigger points in human muscle after slow eccentric exercise. Acupunct Med 2004, 22:2-12.

194. Sheng S, Chen D, Van Eyk JE: Multidimensional liquid chromatography separation of intact proteins by chromatographic focusing and reversed phase of the human serum proteome: optimization and protein database. Mol Cell Proteomics 2006, 5:26-34.

195. Davies TF: Trauma and pressure explain the clinical presentation of the Graves' disease triad. Thyroid 2000, 1 0:629-630.

196. Feng TP: The effect of length on the resting metabolism of muscle. J Physiol | 932, 74:44|-454.

197. Carlsen F, Knappeis GG, Buchthal F: Ultrastructure of the resting and contracted striated muscle fiber at different degrees of stretch. J Biophys Biochem Cytol 196I, I I:95-II7.

198. Nosaka K, Newton M: Concentric or eccentric training effect on eccentric exercise-induced muscle damage. Med Sci Sports Exerc 2002, 34:63-69.

199. Morgan DL: New insights into the behavior of muscle during active lengthening. Biophys / 1990, 57:209-22I.

200. Enns D, Green H, Tupling R, Burnett M, Grant S, Ranney D: Alterations in sarcoplasmic reticulum function in female vastus lateralis with eccentric exercise. Mol Cell Biochem 1999, 202:19-30.
20I. Proske U, Morgan DL: Muscle damage from eccentric exercise: mechanism, mechanical signs, adaptation and clinical applications. J Physiol 200I, 537:333-345.

202. Chen YW, Hubal MJ, Hoffman EP, Thompson PD, Clarkson PM: Molecular responses of human muscle to eccentric exercise. J Appl Physiol 2003, 95:2485-2494.

203. Malm C: Exercise-induced muscle damage and inflammation: fact or fiction? Acta Physiol Scand 200I, I 7 I:233-239.

204. Yu JG, Malm C, Thornell LE: Eccentric contractions leading to DOMS do not cause loss of desmin nor fibre necrosis in human muscle. Histochem Cell Biol 2002, I I 8:29-34.

205. Kirchhefer U, Hanske G, Jones LR, Justus I, Kaestner L, Lipp P Schmitz W, Neumann J: Overexpression of junctin causes adaptive changes in cardiac myocyte $\mathbf{C a}(2+)$ signaling. Cell Calcium 2006, 39:13|-142.

206. Allen DG: Eccentric muscle damage: mechanisms of early reduction of force. Acta Physiol Scand 2001, I 7 I:3 I I-319.

207. Prasartwuth O, Taylor JL, Gandevia SC: Maximal force, voluntary activation and muscle soreness after eccentric damage to human elbow flexor muscles. J Physiol 2005, 567:337-348.

208. Dutto DJ, Braun WA: DOMS-associated changes in ankle and knee joint dynamics during running. Med Sci Sports Exerc 2004, 36:560-566.

209. Brown SJ, Child RB, Day SH, Donnelly AE: Indices of skeletal muscle damage and connective tissue breakdown following eccentric muscle contractions. Eur J Appl Physiol Occup Physiol 1997, 75:369-374.

210. Mair J, Koller A, Artner-Dworzak E, Haid C, Wicke K, Judmaier W, Puschendorf B: Effects of exercise on plasma myosin heavy chain fragments and MRI of skeletal muscle. J Appl Physiol I992, 72:656-663.

21 I. Sorichter S, Mair J, Koller A, Gebert W, Rama D, Calzolari C, ArtnerDworzak E, Puschendorf B: Skeletal troponin I as a marker of exercise-induced muscle damage. I Appl Physiol 1997, 83: $1076-1082$.

212. Jayaraman RC, Reid RW, Foley JM, Prior BM, Dudley GA, Weingand KW, Meyer RA: MRI evaluation of topical heat and static stretching as therapeutic modalities for the treatment of eccentric exercise-induced muscle damage. Eur J Appl Physiol 2004, 93:30-38.

213. Tascilar M, de Jong FA, Verweij J, Mathijssen RH: Complementary and alternative medicine during cancer treatment: beyond innocence. Oncologist 2006, I I:732-74I.

214. Williamson EM: Drug interactions between herbal and prescription medicines. Drug Saf 2003, 26:1075-1092.

215. Ingalls CP, Warren GL, Williams JH, Ward CW, Armstrong RB: E-C coupling failure in mouse EDL muscle after in vivo eccentric contractions. J Appl Physiol 1998, 85:58-67.

216. Takekura $H$, Fujinami $N$, Nishizawa $T$, Ogasawara $H$, Kasuga $N$ : Eccentric exercise-induced morphological changes in the membrane systems involved in excitation-contraction coupling in rat skeletal muscle. J Physiol 200I, :533:57 I-583.

217. Lynn R, Morgan DL: Decline running produces more sarcomeres in rat vastus intermedius muscle fibers than does incline running. J Appl Physiol 1994, 77:|439-1444.

218. Brockett CL, Morgan DL, Proske U: Predicting hamstring strain injury in elite athletes. Med Sci Sports Exerc 2004, 36:379-387.

219. Nosaka K, Clarkson PM: Changes in indicators of inflammation after eccentric exercise of the elbow flexors. Med Sci Sports Exerc 1996, 28:953-961

220. Barash IA, Mathew L, Ryan AF, Chen J, Lieber RL: Rapid musclespecific gene expression changes after a single bout of eccentric contractions in the mouse. Am J Physiol Cell Physiol 2004, 286: $C 355-C 364$

22I. Sorrentino V: Molecular determinants of the structural and functional organization of the sarcoplasmic reticulum. Biochim Biophys Acta 2004, I 742: I I3-I I8.

222. Armani A, Galli S, Giacomello E, Bagnato P, Barone V, Rossi D, Sorrentino V: Molecular interactions with obscurin are involved in the localization of muscle-specific small ankyrin I isoforms to subcompartments of the sarcoplasmic reticulum. Exp Cell Res 2006, 3 I 2:3546-3558.

223. Stauber WT, Clarkson PM, Fritz VK, Evans W]: Extracellular matrix disruption and pain after eccentric muscle action. J Appl Physiol 1990, 69:868-874. 
224. Whitehead NP, Weerakkody NS, Gregory JE, Morgan DL, Proske U: Changes in passive tension of muscle in humans and animals after eccentric exercise. J Physiol 200I, 533:593-604

225. Gregory JE, Brockett CL, Morgan DL, Whitehead NP, Proske U: Effect of eccentric muscle contractions on Golgi tendon organ responses to passive and active tension in the cat. J Physiol 2002, 538:209-218.

226. Riley G: The pathogenesis of tendinopathy. A molecular perspective. Rheumatology (Oxford) 2004, 43:|3|-|42.

227. Manoli A, Weber TG: Fasciotomy of the foot: an anatomical study with special reference to release of the calcaneal compartment. Foot Ankle 1990, 10:267-275.

228. Toumi $H$, Best TM: The inflammatory response: friend or enemy for muscle injury? Br J Sports Med 2003, 37:284-286.

229. Jonsdottir IH, Schjerling P, Ostrowski K, Asp S, Richter EA, Pedersen BK: Muscle contractions induce interleukin-6 mRNA production in rat skeletal muscles. J Physiol 2000, 528 Pt I:I57-I63.

230. Bennermo M, Held C, Stemme S, Ericsson CG, Silveira A, Green F, Tornvall P: Genetic predisposition of the interleukin-6 response to inflammation: implications for a variety of major diseases? Clin Chem 2004, 50:2136-2I40.

23I. Liuzzi JP, Lichten LA, Rivera S, Blanchard RK, Aydemir TB, Knutson MD, Ganz T, Cousins RJ: Interleukin-6 regulates the zinc transporter Zip 14 in liver and contributes to the hypozincemia of the acute-phase response. Proc Natl Acad Sci U S A 2005, 1 02:6843-6848.

232. Toft AD, Jensen LB, Bruunsgaard H, Ibfelt T, Halkjaer-Kristensen J, Febbraio M, Pedersen BK: Cytokine response to eccentric exercise in young and elderly humans. Am J Physiol Cell Physiol 2002, 283:C289-C295.

233. Stupka N, Tarnopolsky MA, Yardley NJ, Phillips SM: Cellular adaptation to repeated eccentric exercise-induced muscle damage. J Appl Physiol 2001, 91:1669-1678.

234. Marqueste $T$, Decherchi $P$, Messan F, Kipson N, Grelot L, Jammes $Y$ : Eccentric exercise alters muscle sensory motor control through the release of inflammatory mediators. Brain Res 2004, 1023:222-230.

235. Stupka N, Lowther S, Chorneyko K, Bourgeois JM, Hogben C, Tarnopolsky MA: Gender differences in muscle inflammation after eccentric exercise. I Appl Physiol 2000, 89:2325-2332.

236. Vassilakopoulos T, Karatza MH, Katsaounou P, Kollintza A, Zakynthinos S, Roussos C: Antioxidants attenuate the plasma cytokine response to exercise in humans. J Appl Physiol 2003, 94:1025-1032.

237. Boppart MD, Aronson D, Gibson L, Roubenoff R, Abad LW, Bean J, Goodyear LJ, Fielding RA: Eccentric exercise markedly increases c-Jun NH(2)-terminal kinase activity in human skeletal muscle. J Appl Physiol 1999, 87: 1668-1673.

238. Franzini-Armstrong $C$ : The sarcoplasmic reticulum and the control of muscle contraction. FASEB I 1999, I3 Supp 2:S266-S270.

239. Schulz JS, Palmer N, Steckelberg J, Jones SJ, Zeece MG: Microarray profiling of skeletal muscle sarcoplasmic reticulum proteins. Biochim Biophys Acta 2006, I 764: | 429-|435.

240. Györke I, Hester N, Jones LR, Györke S: The role of calseques trin, triadin, and junctin in conferring cardiac ryanodine receptor responsiveness to luminal calcium. Biophys J 2004, 86:2|2|-2|28

24I. Marie V, Silva JE: Calcium pool size modulates the sensitivity of the ryanodine receptor channel and calcium-dependent ATPase of heavy sarcoplasmic reticulum to extravesicular free calcium concentration. J Cell Physiol I 998, I 75:283-294.

242. Wagenknecht T, Berkowitz J, Grassucci R, Timerman AP, Fleischer S: Localization of calmodulin binding sites on the ryanodine receptor from skeletal muscle by electron microscopy. Biophys J 1994, 67:2286-2295.

243. van den Bosch L, Schwaller B, Vleminckx V, Meijers B, Stork S, Rueh licke T, Van Houtte E, Klaassen H, Celio MR, Missiaen L, Robberecht W, Berchtold MW: Protective effect of parvalbumin on excitotoxic motor neuron death. Exp Neurol 2002, I74:150-16I.

244. Kjellgren D, Ryan M, Ohlendieck K, Thornell LE, Pedrosa-Domellöf F: Sarco(endo)plasmic reticulum Ca2+ ATPases (SERCAI and -2) in human extraocular muscles. Invest Ophthalmol Vis Sci 2003. 44:5057-5062.

245. Simonides WS, Thelen $M H$, van der Linden CG, Muller A, van Hardeveld $C$ : Mechanism of thyroid-hormone regulated expres- sion of the SERCA genes in skeletal muscle: implications for thermogenesis. Biosci Rep 200 I, 2 I: I39-I54.

246. Arruda AP, Oliveira GM, Carvalho DP, De Meis L: Thyroid hormones differentially regulate the distribution of rabbit skeletal muscle $\mathrm{Ca}(2+)$-ATPase (SERCA) isoforms in light and heavy sarcoplasmic reticulum. Mol Membr Biol 2005 , 22:529-537.

247. Hornberger TA, Chien S: Mechanical stimuli and nutrients regulate rapamycin-sensitive signaling through distinct mechanisms in skeletal muscle. J Cell Biochem 2006, 97: I 207-12 I6.

248. Hornberger TA, Sukhija KB, Chien S: Regulation of $\mathbf{m T O R}$ by mechanically induced signaling events in skeletal muscle. Cell Cycle 2006, 5:1391-1396

249. Darr KC, Schultz E: Exercise-induced satellite cell activation in growing and mature skeletal muscle. J Appl Physiol 1987. 63: $1816-1821$.

250. Allen DL, Roy RR, Edgerton VR: Myonuclear domains in muscle adaptation and disease. Muscle Nerve 1999, 22:1350-1360.

25I. Anderson JE: The satellite cell as a companion in skeletal mus cle plasticity: currency, conveyance, clue, connector and colander. J Exp Biol 2006, 209:2276-2292.

252. Carmeli E, Moas M, Reznick AZ, Coleman R: Matrix metalloproteinases and skeletal muscle: a brief review. Muscle Nerve 2004 29:191-197.

253. Yu JG, Fürst DO, Thornell LE: The mode of myofibril remodelling in human skeletal muscle affected by DOMS induced by eccentric contractions. Histochem Cell Biol 2003, I I 9:383-393.

254. Collins M, Renault V, Grobler LA, St Clair GA, Lambert MI, Wayne DE, Butler-Browne GS, Noakes TD, Mouly V: Athletes with exercise-associated fatigue have abnormally short muscle DNA telomeres. Med Sci Sports Exerc 2003, 35:1524-I 528.

255. Silver FH, Siperko LM: Mechanosensing and mechanochemical transduction: how is mechanical energy sensed and converted into chemical energy in an extracellular matrix? Crit Rev Biomed Eng 2003, 3 I:255-33I.

256. Kung C: $\mathbf{A}$ possible unifying principle for mechanosensation. Nature 2005, 436:647-654

257. Silver FH, Siperko LM, Seehra GP: Mechanobiology of force transduction in dermal tissue. Skin Res Technol 2003, 9:3-23.

258. Powers SK, Lennon SL: Analysis of cellular responses to free radicals: focus on exercise and skeletal muscle. Proc Nutr Soc 1999, 58:1025-1033.

259. Kieseier BC, Schneider C, Clements JM, Gearing AJ, Gold R, Toyka $\mathrm{KV}$, Hartung HP: Expression of specific matrix metalloproteinases in inflammatory myopathies. Brain 200I, | 24:34|-35 I.

260. Koskinen SO, Heinemeier KM, Olesen JL, Langberg H, Kjaer M: Physical exercise can influence local levels of matrix metalloproteinases and their inhibitors in tendon-related connective tissue. J Appl Physiol 2004, 96:86I-864.

26I. Villarreal CF, Del Bel EA, Prado WA: Involvement of the anterior pretectal nucleus in the control of persistent pain: a behavioral and c-Fos expression study in the rat. Pain 2003, 103:163-174.

262. Rowbottom DG, Keast D, Green S, Kakulas B, Morton AR: The case history of an elite ultra-endurance cyclist who developed chronic fatigue syndrome. Med Sci Sports Exerc 1998, 30: $1345-1348$

263. Enoka RM: Eccentric contractions require unique activation strategies by the nervous system. I Appl Physiol 1996 8I:2339-2346.

264. Dias JM, Szegedi C, Jona I, Vogel PD: Insights into the Regulation of the Ryanodine Receptor: Differential Effects of $\mathbf{M g ( 2 + )}$ and $\mathrm{Ca}(2+)$ on ATP Binding. Biochemistry 2006, 45:9408-94I5.

265. Thorlacius-Ussing $O$, Jensen FT: Selenium in the anterior pituitary of the rat after a single injection of $75 \mathrm{Se}$ sodium selenite. Biol Trace Elem Res 1988, I 5:277-287.

266. Rederstorff $M$, Krol A, Lescure A: Understanding the importance of selenium and selenoproteins in muscle function. Cell Mol Life Sci 2006, 63:52-59.

267. Lu C, Qiu F, Zhou H, Peng Y, Hao W, Xu J, Yuan J, Wang S, Qiang B $\mathrm{Xu} C$, Peng $\mathrm{X}$ : Identification and characterization of selenoprotein K: an antioxidant in cardiomyocytes. FEBS Lett 2006 580:5189-5197.

268. Hornberger TA, McLoughlin TJ, Leszczynski JK, Armstrong DD, Jameson RR, Bowen PE, Hwang ES, Hou H, Moustafa ME, Carlson BA, Hatfield DL, Diamond AM, Esser KA: Selenoprotein-deficient 
transgenic mice exhibit enhanced exercise-induced muscle growth. J Nutr 2003, 133:3091-3097.

269. Curran JE, Jowett JB, Elliott KS, Gao Y, Gluschenko K, Wang J, Abe Azim DM, Cai G, Mahaney MC, Comuzzie AG, Dyer TD, Walder KR, Zimmet P, MacCluer JW, Collier GR, Kissebah AH, Blangero J: Genetic variation in selenoprotein $\mathbf{S}$ influences inflammatory response. Nat Genet 2005, 37: 234- I24I.

270. Moghadaszadeh B, Petit N, Jaillard C, Brockington M, Roy SQ, Merlini L, Romero N, Estournet B, Desguerre I, Chaigne D, Muntoni F, Topaloglu $\mathrm{H}$, Guicheney P: Mutations in SEPNI cause congenital muscular dystrophy with spinal rigidity and restrictive respiratory syndrome. Nat Genet 200I, 29:17-18.

27I. Clarke NF, Kidson W, Quijano-Roy S, Estournet B, Ferreiro A, Guicheney P, Manson JI, Kornberg AJ, Shield LK, North KN: SEPN I: associated with congenital fiber-type disproportion and insulin resistance. Ann Neurol 2006, 59:546-552.

272. Loflin J, Lopez N, Whanger PD, Kioussi C: Selenoprotein W during development and oxidative stress. J Inorg Biochem 2006, 100:1679-1684.

273. Joseph K, Kaplan AP: Formation of bradykinin: a major contributor to the innate inflammatory response. Adv Immunol 2005 , 86:159-208

274. Permiakov EA, Kalinichenko LA, Morozova LA, Derezhkov IV Bagelova J: [Interaction of copper and zinc cations with calcium-binding proteins]. Mol Biol (Mosk) I988, 22:984-99।.

275. Pekary AE, Lukaski HC, Mena I, Hershman JM: Processing of TRH precursor peptides in rat brain and pituitary is zinc dependent. Peptides 1991, I 2:1025-1032.

276. Lynch C], Patson BJ, Goodman SA, Trapolsi D, Kimball SR: Zinc stimulates the activity of the insulin- and nutrient-regulated protein kinase mTOR. Am J Physiol Endocrinol Metab 200I, 28I:E25-E34.

277. Smart TG, Hosie AM, Miller PS: Zn2+ ions: modulators of excitatory and inhibitory synaptic activity. Neuroscientist 2004, 10:432-442.

278. Wang ZY, Li JY, Varea E, Danscher G, Dahlstrom A: Is the postganglionic sympathetic neuron zinc-enriched? A stop-flow nerve crush study on rat sciatic nerve. Neuroreport 200I, 1 2:2247-2250

279. Thorlacius-Ussing O, Danscher G, Moller-Madsen B, Rungby J: Selenium in the anterior pituitary. Sci Total Environ $1985,42: 185-188$

280. Evans WJ: Vitamin E, vitamin C, and exercise. Am J Clin Nutr 2000, 72:647S-652S.

28I. Clement K, Viguerie N, Diehn M, Alizadeh A, Barbe P, Thalamas C, Storey JD, Brown PO, Barsh GS, Langin D: In vivo regulation of human skeletal muscle gene expression by thyroid hormone. Genome Res 2002, 12:28I-291.

282. Yamada T, Inashima S, Matsunaga S, Nara I, Kajihara H, Wada M: Different time course of changes in sarcoplasmic reticulum and myosin isoforms in rat soleus muscle at early stage of hyperthyroidism. Acta Physiol Scand 2004, 180:79-87.

283. Thelen MH, Simonides WS, Muller A, van Hardeveld C: Cross-talk between transcriptional regulation by thyroid hormone and myogenin: new aspects of the $\mathrm{Ca2+-dependent} \mathrm{expression} \mathrm{of}$ the fast-type sarcoplasmic reticulum $\mathrm{Ca2}+$-ATPase. Biochem J 1998, 329:131-136.

284. Jacobs SC, Bar PR, Bootsma AL: Effect of hypothyroidism on satellite cells and postnatal fiber development in the soleus muscle of rat. Cell Tissue Res 1996, 286: I37-I 44

285. Yamada T, Mishima T, Sakamoto M, Sugiyama M, Matsunaga S, Wada $M$ : Oxidation of myosin heavy chain and reduction in force production in hyperthyroid rat soleus. J Appl Physiol 2006 100:1520-1526.

286. Yamada T, Wada M: Effects of thyroid hormone on sarcoplasmic reticulum $\mathrm{Ca2}+$ uptake and contractile properties in rat soleus muscle. Jpn J Phys Fitness Sports Med 2004, 53:509-5 I8.

287. Kirwan JP, Hickner RC, Yarasheski KE, Kohrt WM, Wiethop BV, Holloszy JO: Eccentric exercise induces transient insulin resistance in healthy individuals. J Appl Physiol 1992, 72:2 197-2202.

288. Bergfors M, Barnekow-Bergkvist M, Kalezic N, Lyskov E, Eriksson JW: Short-term effects of repetitive arm work and dynamic exercise on glucose metabolism and insulin sensitivity. Acta Physiol Scand 2005, 183:345-356.

289. Widrick JJ, Costill DL, McConell GK, Anderson DE, Pearson DR, Zachwieja Jl: Time course of glycogen accumulation after eccentric exercise. J Appl Physiol 1992, 72:1999-2004.
290. Villadolid MC, Yokoyama N, Izumi M, Nishikawa T, Kimura H, Ashizaya K, Kiriyama T, Uetani M, Nagataki S: Untreated Graves' disease patients without clinical ophthalmopathy demonstrate a high frequency of extraocular muscle (EOM) enlargement by magnetic resonance. J Clin Endocrinol Metab 1995, 80:2830-2833.

29I. Nagy EV, Toth J, Kaldi I, Damjanovich J, Mezosi E, Lenkey A, Toth L, Szabo J, Karanyi Z, Leovey A: Graves' ophthalmopathy: eye muscle involvement in patients with diplopia. Eur J Endocrinol 2000, 142:59|-597.

292. Schmidt ED, van Hogerwou G, Van der Gaag R, Wiersinga WM, Asmussen G, Koornneef L: Site-dependent effects of experimental hypo- and hyperthyroidism on resident macrophages in extraocular muscles of rats: a quantitative immunohistochemical study. J Endocrinol 1992, 135:485-493.

293. Schmidt ED, Van der Gaag R, Ganpat R, Broersma L, de Boer PA, Moorman AF, Lamers WH, Wiersinga WM, Koornneef L: Distribution of the nuclear thyroid-hormone receptor in extraocular and skeletal muscles. J Endocrinol 1992, 133:67-74.

294. McLoon LK, Wirtschafter J: Activated satellite cells in extraocular muscles of normal adult monkeys and humans. Invest Ophthalmol Vis Sci 2003, 44: 1927-1932.

295. McLoon LK, Rowe J, Wirtschafter J, McCormick KM: Continuous myofiber remodeling in uninjured extraocular myofibers: myonuclear turnover and evidence for apoptosis. Muscle Nerve 2004, 29:707-7I5.

296. Antunes-Foschini RM, Ramalho FS, Ramalho LN, Bicas HE: Increased frequency of activated satellite cells in overacting inferior oblique muscles from humans. Invest Ophthalmol Vis Sci 2006, 47:3360-3365.

297. Jahn K, Kalla R, Karg S, Strupp M, Brandt T: Eccentric eye and head positions in darkness induce deviation from the intended path. Exp Brain Res 2006, 174:152-157.

298. Han Y, Lennerstrand G: Eye position changes induced by neck muscle vibration in strabismic subjects. Graefes Arch Clin Exp Ophthalmol 1999, 237:21-28.

299. Petit L, Beauchamp MS: Neural basis of visually guided head movements studied with fMRI. I Neurophysiol 2003, 89:2516-2527.

300. Misiaszek JE: Early activation of arm and leg muscles following pulls to the waist during walking. Exp Brain Res 2003, I5I:318-329.

30I. Demer JL: Current concepts of mechanical and neural factors in ocular motility. Curr Opin Neurol 2006, 19:4-13.

302. Fischer MD, Gorospe JR, Felder E, Bogdanovich S, Pedrosa-Domellö F, Ahima RS, Rubinstein NA, Hoffman EP, Khurana TS: Expression profiling reveals metabolic and structural components of extraocular muscles. Physiol Genomics 2002, 9:7I-84.

303. Fischer MD, Budak MT, Bakay M, Gorospe JR, Kjellgren D, PedrosaDomellöf F, Hoffman EP, Khurana TS: Definition of the unique human extraocular muscle allotype by expression profiling. Physiol Genomics 2005, 22:283-291.

304. Welle S, Brooks AI, Delehanty JM, Needler N, Thornton CA: Gene expression profile of aging in human muscle. Physiol Genomics 2003, I4:149-159.

305. Debaere F, Swinnen SP, Beatse E, Sunaert S, Van Hecke P, Duysens ]: Brain areas involved in interlimb coordination: a distributed network. Neuroimage 200I, 14:947-958.

306. Ciccarelli O, Toosy AT, Marsden JF, Wheeler-Kingshott CM, Miller $\mathrm{DH}$, Matthews PM, Thompson AJ: Functional response to active and passive ankle movements with clinical correlations in patients with primary progressive multiple sclerosis. J Neurol 2006, 253:882-891.

307. MacLennan $\mathrm{DH}: \mathbf{C a 2 +}$ signalling and muscle disease. Eur J Biochem 2000, 267:5291-5297.

308. Vangheluwe P, Schuermans M, Zador E, Waelkens E, Raeymaekers L, Wuytack F: Sarcolipin and phospholamban mRNA and protein expression in cardiac and skeletal muscle of different species. Biochem / 2005, 389:151-159.

309. MacLennan DH, Asahi M, Tupling AR: The regulation of SERCAtype pumps by phospholamban and sarcolipin. Ann $N$ Y Acad Sci 2003, 986:472-480

310. Knollmann BC, Chopra N, Hlaing T, Akin B, Yang T, Ettensohn K, Knollmann BE, Horton KD, Weissman NJ, Holinstat I, Zhang W, Roden DM, Jones LR, Franzini-Armstrong C, Pfeifer K: Casq2 deletion causes sarcoplasmic reticulum volume increase, prema- 
ture $\mathrm{Ca2+}$ release, and catecholaminergic polymorphic ventricular tachycardia. J Clin Invest 2006, I I 6:25 I0-2520.

311. Li J, Puceat M, Perez-Terzic C, Mery A, Nakamura K, Michalak M, Krause $\mathrm{KH}$, Jaconi ME: Calreticulin reveals a critical $\mathbf{C a}(2+)$ checkpoint in cardiac myofibrillogenesis. J Cell Biol 2002, I 58:103-II3.

312. Guerini $D$ : The $\mathrm{Ca} 2+$ pumps and the $\mathrm{Na}+\mathrm{Ca} 2+$ exchangers. Biometals 1998, II:319-330.

313. Suzuki YJ, Ford GD: Redox regulation of signal transduction in cardiac and smooth muscle. J Mol Cell Cardiol 1999, 3 I:345-353.

314. Gouadon E, Schuhmeier RP, Ursu D, Anderson AA, Treves S, Zorzato $F$, Lehmann-Horn F, Melzer W: A possible role of the junctional face protein JP-45 in modulating $\mathrm{Ca} 2+$ release in skeletal muscle. J Physiol 2006, 572:269-280

315. Sun J, Xu L, Eu JP, Stamler JS, Meissner G: Classes of thiols that influence the activity of the skeletal muscle calcium release channel. J Biol Chem 200I, 276: I5625-I5630.

316. Banhegyi G, Csala M, Nagy G, Sorrentino V, Fulceri R, Benedetti A: Evidence for the transport of glutathione through ryanodine receptor channel type I. Biochem J 2003, 376:807-8I2.

317. Xia R, Ganther HE, Egge A, Abramson J]: Selenium compounds modulate the calcium release channel/ryanodine receptor of rabbit skeletal muscle by oxidizing functional thiols. Biochem Pharmacol 2004, 67:207I-2079.

318. Jiang M, Xu A, Tokmakejian S, Narayanan N: Thyroid hormoneinduced overexpression of functional ryanodine receptors in the rabbit heart. Am J Physiol Heart Circ Physiol 2000, 278: HI 429-HI438.

319. Fruen BR, Bardy JM, Byrem TM, Strasburg GM, Louis CF: Differential $\mathrm{Ca}(2+)$ sensitivity of skeletal and cardiac muscle ryanodine receptors in the presence of calmodulin. Am J Physiol Cell Physiol 2000, 279:C724-C733.

320. Heizmann CW, Cox JA: New perspectives on S 100 proteins: a multi-functional $\mathrm{Ca}(2+)-, \mathrm{Zn}(2+)$ - and $\mathrm{Cu}(2+)$-binding protein family. Biometals 1998, I I:383-397.

32I. Johansson C, Lunde PK, Gothe S, Lannergren J, Westerblad H: Isometric force and endurance in skeletal muscle of mice devoid of all known thyroid hormone receptors. J Physiol 2003, 547:789-796.

322. Petit N, Lescure A, Rederstorff M, Krol A, Moghadaszadeh B, Wewer UM, Guicheney P: Selenoprotein N: an endoplasmic reticulum glycoprotein with an early developmental expression pattern. Hum Mol Genet 2003, I 2: I045-1053.

323. Jungbluth $\mathrm{H}$, Zhou H, Hartley L, Halliger-Keller B, Messina S, Longman C, Brockington M, Robb SA, Straub V, Voit T, Swash M, Ferreiro A Bydder G, Sewry CA, Müller C, Muntoni F: Minicore myopathy with ophthalmoplegia caused by mutations in the ryanodine receptor type I gene. Neurology 2005, 65:1930-1935.

324. Yeh JY, Beilstein MA, Andrews JS, Whanger PD: Tissue distribution and influence of selenium status on levels of selenoprotein W. FASEB J 1995, 9:392-396.

325. Gu QP, Sun Y, Ream LW, Whanger PD: Selenoprotein W accumulates primarily in primate skeletal muscle, heart, brain and tongue. Mol Cell Biochem 2000, 204:49-56.

326. Xia RH, Cheng XY, Wang H, Chen KY, Wei QQ, Zhang XH, Zhu PH: Biphasic modulation of ryanodine binding to sarcoplasmic reticulum vesicles of skeletal muscle by $\mathbf{Z n 2 +}$ ions. Biochem J 2000, 345 Pt 2:279-286.

327. Palmer BM, Vogt S, Chen Z, Lachapelle RR, Lewinter MM: Intracellular distributions of essential elements in cardiomyocytes. $J$ Struct Biol 2006, 155:12-2I.

328. Vettakkorumakankav NN, Ananthanarayanan VS: $\mathbf{C a}(2+)$ and $\mathrm{Zn}(2+)$ binding properties of peptide substrates of vertebrate collagenase, MMP-I. Biochim Biophys Acta 1999 I 432:356-370.

329. Kondo H, Kimura M, Itokawa Y: Manganese, copper, zinc, and iron concentrations and subcellular distribution in two types of skeletal muscle. Proc Soc Exp Biol Med 1991, 196:83-88.

330. Miranda M, Alonso ML, Benedito JL: Copper, zinc, iron, and manganese accumulation in cattle from asturias (northern Spain). Biol Trace Elem Res 2006, 109:135-143.

33I. Carmeli E, Coleman R, Reznick AZ: The biochemistry of aging muscle. Exp Gerontol 2002, 37:477-489.

332. Roubenoff $R$ : Catabolism of aging: is it an inflammatory process? Curr Opin Clin Nutr Metab Care 2003, 6:295-299.
333. Schaap LA, Pluijm SM, Deeg DJ, Visser M: Inflammatory markers and loss of muscle mass (sarcopenia) and strength. Am J Med 2006, II 9:526-17.

334. Weaver JD, Huang MH, Albert M, Harris T, Rowe JW, Seeman TE: Interleukin-6 and risk of cognitive decline: MacArthur studies of successful aging. Neurology 2002, 59:37I-378.

335. Richwine AF, Godbout JP, Berg BM, Chen J, Escobar J, Millard DK, Johnson RW: Improved psychomotor performance in aged mice fed diet high in antioxidants is associated with reduced ex vivo brain interleukin-6 production. Brain Behav Immun 2005, 19:5। 2-520

336. Barbieri M, Ferrucci L, Ragno E, Corsi A, Bandinelli S, Bonafe M, Olivieri F, Giovagnetti S, Franceschi C, Guralnik JM, Paolisso G: Chronic inflammation and the effect of IGF-I on muscle strength and power in older persons. Am J Physiol Endocrinol Metab 2003, 284:E48I-E487.

337. Febbraio MA, Steensberg A, Keller C, Starkie RL, Nielsen HB, Krustrup $\mathrm{P}$, Ott $\mathrm{P}$, Secher $\mathrm{NH}$, Pedersen BK: Glucose ingestion attenuates interleukin- 6 release from contracting skeletal muscle in humans. J Physiol 2003, 549:607-6I2.

338. Fischer CP, Berntsen A, Perstrup LB, Eskildsen P, Pedersen BK: Plasma levels of interleukin-6 and C-reactive protein are associated with physical inactivity independent of obesity. Scand J Med Sci Sports 2006, ...

339. Grimble RF: Inflammatory status and insulin resistance. Curr Opin Clin Nutr Metab Care 2002, 5:55I-559.

340. Yang $X$, Jansson PA, Pellme F, Laakso M, Smith U: Effect of the interleukin-6 (-174) g/c promoter polymorphism on adiponectin and insulin sensitivity. Obes Res 2005, 13:8|3-8I7.

34I. Baines A, Taylor-Parker M, Goulet AC, Renaud C, Gerner EW, Nelson MA: Selenomethionine inhibits growth and suppresses cyclooxygenase-2 (COX-2) protein expression in human colon cancer cell lines. Cancer Biol Ther 2002, I:370-374.

342. Reiterer G, Toborek M, Hennig B: Peroxisome proliferator activated receptors alpha and gamma require zinc for their antiinflammatory properties in porcine vascular endothelial cells. J Nutr 2004, 134: 171।-1715.

343. Kretz-Remy C, Arrigo AP: Selenium: a key element that controls NF-kappa B activation and I kappa B alpha half life. Biofactors 200I, I4:1 I7-125.

344. Heart E, Sung CK: Insulin-like and non-insulin-like selenium actions in 3T3-LI adipocytes. / Cell Biochem 2003, 88:719-73I.

345. Rumsey SC, Kwon O, Xu GW, Burant CF, Simpson I, Levine M: Glucose transporter isoforms GLUTI and GLUT3 transport dehydroascorbic acid. I Biol Chem 1997, 272:18982-I8989.

346. Padayatty SJ, Levine $\mathrm{M}$ : New insights into the physiology and pharmacology of vitamin C. CMAJ 200I, 164:353-355.

347. Helmersson J, Arnlov J, Vessby B, Larsson A, Alfthan G, Basu S: Serum selenium predicts levels of F2-isoprostanes and prostaglandin F2a in a 27 year follow-up study of Swedish men. Free Radic Res 2005, 39:763-770.

348. Rivera-Chavez FA, Peters-Hybki DL, Barber RC, O'Keefe GE: Interleukin-6 promoter haplotypes and interleukin-6 cytokine responses. Shock 2003, 20:218-223.

349. Ostrowski K, Rohde T, Zacho M, Asp S, Pedersen BK: Evidence that interleukin-6 is produced in human skeletal muscle during prolonged running. J Physiol 1998, 508:949-953.

350. Tomas E, Kelly M, Xiang X, Tsao TS, Keller C, Keller P, Luo Z, Lodish $\mathrm{H}$, Saha AK, Unger R, Ruderman NB: Metabolic and hormonal interactions between muscle and adipose tissue. Proc Nutr Soc 2004, 63:38I-385

35I. Fernandez-Real JM, Vayreda M, Richart C, Gutierrez C, Broch M, Vendrell J, Ricart W: Circulating interleukin 6 levels, blood pressure, and insulin sensitivity in apparently healthy men and women. J Clin Endocrinol Metab 200 I, 86: I I54-I I 59.

352. Straub RH, Vogl D, Gross V, Lang B, Scholmerich J, Andus T: Association of humoral markers of inflammation and dehydroepiandrosterone sulfate or cortisol serum levels in patients with chronic inflammatory bowel disease. $\mathrm{Am}$ J Gastroenterol 1998, 93:2197-2202.

353. Goebel MU, Mills PJ, Irwin MR, Ziegler MG: Interleukin-6 and tumor necrosis factor-alpha production after acute psychological stress, exercise, and infused isoproterenol: differential effects and pathways. Psychosom Med 2000, 62:59।-598.

354. Mocchegiani E, Muzzioli M, Giacconi R, Cipriano C, Gasparini N, Franceschi C, Gaetti R, Cavalieri E, Suzuki H: Metallothioneins/ 
PARP-I/IL-6 interplay on natural killer cell activity in elderly: parallelism with nonagenarians and old infected humans. Effect of zinc supply. Mech Ageing Dev 2003, I 24:459-468.

355. Nemeth E, Rivera S, Gabayan V, Keller C, Taudorf S, Pedersen BK, Ganz T: IL-6 mediates hypoferremia of inflammation by inducing the synthesis of the iron regulatory hormone hepcidin. J Clin Invest 2004, I I 3:127|- 1276.

356. Boiardi L, Casali B, Farnetti E, Pipitone N, Nicoli D, Cantini F, Macchioni P, Bajocchi G, Catanoso MG, Pulsatelli L, Consonni D, Salvarani C: Relationship between interleukin 6 promoter polymorphism at position -174, IL-6 serum levels, and the risk of relapse/recurrence in polymyalgia rheumatica. I Rheumatol 2006, 33:703-708.

357. Paloski WH, Wood SJ, Feiveson AH, Black FO, Hwang EY, Reschke MF: Destabilization of human balance control by static and dynamic head tilts. Gait Posture 2005, 23:31 5-323.

358. Vuillerme N, Rougier P: Effects of head extension on undisturbed upright stance control in humans. Gait Posture 2005, 21:318-325.

359. Wolsley CJ, Sakellari V, Bronstein AM: Reorientation of visually evoked postural responses by different eye-in-orbit and head-on-trunk angular positions. Exp Brain Res 1996, I I I:283-288.

360. Leitao P, Nanda RS: Relationship of natural head position to craniofacial morphology. Am J Orthod Dentofacial Orthop 2000, I I 7:406-4I7.

36I. Zepa I, Hurmerinta K, Kovero O, Nissinen M, Kononen M, Huggare $\mathrm{J}$ : Trunk asymmetry and facial symmetry in young adults. Acta Odontol Scand 2003, 61:149-153.

362. Patla AE, Adkin A, Ballard T: Online steering: coordination and control of body center of mass, head and body reorientation. Exp Brain Res 1999, 129:629-634.

363. Mens J, Hoek van Dijke G, Pool-Goudzwaard A, van der Hulst V, Stam $\mathrm{H}$ : Possible harmful effects of high intra-abdominal pressure on the pelvic girdle. J Biomech 2006, 39:627-635.

364. Nyland J, Kuzemchek S, Parks M, Caborn DN: Femoral anteversion influences vastus medialis and gluteus medius EMG amplitude: composite hip abductor EMG amplitude ratios during isometric combined hip abduction-external rotation. J Electromyogr Kinesiol 2004, 14:255-26I.

365. Hiller CE, Refshauge KM, Beard DJ: Sensorimotor control is impaired in dancers with functional ankle instability. $\mathrm{Am} J$ Sports Med 2004, 32:21 6-223.

366. Bullock-Saxton JE: Local sensation changes and altered hip muscle function following severe ankle sprain. Phys Ther 1994, 74:17-28.

367. Beckman SM, Buchanan TS: Ankle inversion injury and hypermobility: effect on hip and ankle muscle electromyography onset latency. Arch Phys Med Rehabil 1995, 76: I I38-I I 43.

368. Friel K, McLean N, Myers C, Caceres M: Ipsilateral hip abductor weakness after inversion ankle sprain. J Athl Train 2006, 4I:74-78.

369. Kavounoudias A, Gilhodes JC, Roll R, Roll JP: From balance regulation to body orientation: two goals for muscle proprioceptive information processing? Exp Brain Res 1999, 1 24:80-88.

370. Gopinath B, Musselman R, Adams CL, Tani J, Beard N, Wall JR: Study of Serum Antibodies Against Three Eye Muscle Antigens and the Connective Tissue Antigen Collagen XIII in Patients with Graves' Disease With and Without Ophthalmopathy: Correlation With Clinical Features. Thyroid 2006, 16:967-974.

\section{Pre-publication history}

The pre-publication history for this paper can be accessed here:

http://www.biomedcentral.com/1471-2474/8/17/prepub

\section{Publish with Bio Med Central and every scientist can read your work free of charge}

"BioMed Central will be the most significant development for disseminating the results of biomedical research in our lifetime. "

Sir Paul Nurse, Cancer Research UK

Your research papers will be:

- available free of charge to the entire biomedical community

- peer reviewed and published immediately upon acceptance

- cited in PubMed and archived on PubMed Central

- yours - you keep the copyright

Submit your manuscript here:

http://www.biomedcentral.com/info/publishing_adv.asp
BioMedcentral 